\title{
PARAMETERIZATION AND EVALUATION OF INFILTRATION MODELS FOR TWO SOILS PLAINS OF DUHOK REGION UNDER DIFFERENT LANDUSES
}

\author{
Nichirvan Ahmad Muhammad Amin and Akram AbBas KHalaF \\ Dept. of Soil and Water Science, College of Agricultural Engineering Science, University of Duhok, \\ Kurdistan Region
}

(Received: January 17, 2021; Accepted for Publication: March 9, 2021)

\begin{abstract}
The aims of this study were to parameterization and evaluation of two infiltration models for two plains soils under semi-arid conditions with different landuses types, such as cultivated, fallow, and orchard landuses. The infiltration models evaluated were Kostiakov, and Philip.

The research was conducted at the three sites represent two major plains of Duhok governorate of Iraqi-Kurdistan Region.

Two models exhibiting the best performance are Kostiakov, and Philip-two term, Regarding the Kostiakov model, the coefficient parameter value of $(C)$ is directly proportional to the initial infiltration rate whereas the exponential time parameter value of $(n)$ is inversely proportional to the initial infiltration rate. it can be concluded that the value of $\mathrm{C}$ is correlated with the capillary force at the beginning of infiltration, concerning to the Philip model the value of sorptivity $(S)$ was close to the value of the initial infiltration rate. This is due to the function of $S$ parameter which has the soil suction potential and that transmissivity value considered to $\mathbf{0 . 3 3}$ of saturated hydraulic conductivity of soil.

Infiltration models evaluation revealed that the Philip-two term model is more suitable for cultivated land CL and orchard land OL and Kostiakov model fallow landuses FL for the two investigated sites of Semel, and Zakho.
\end{abstract}

KEY WORDS: infiltration models, land use, Kostiakov model, Philip model, Evaluation of model.

\section{INTRODUCTION}

I ncreasing pressures on the land uses, the capture of more rainfall and its efficient storage and use of that water is even becoming an urgent necessity. This implies that water plays a key role in rehabilitation and production improvement, but in Iraqi Kurdistan Region water availability is below the required level (Khalaf, 2010).

Infiltration is one of the major components of the hydrologic cycle. Water that falls as precipitation may run over land eventually reaching streams, lakes, rivers and oceans or infiltrate through the soil surface, into the soil profile and replenishes the ground water supply to wells, springs and streams (Rawls et al., 1993; Oram, 2005).

The ability to quantify infiltration is of great importance in watershed management. Prediction of flooding, erosion and pollutant transport all depend on the rate of runoff which is directly affected by the rate of infiltration. In order to develop improved hydrologic models, accurate methods for characterizing infiltration are required (Shirmohammadi, 1984).

nechirvan.ahmed@uod.ac;
There are several factors contributing to the rate of infiltration, including time from rain or irrigation initiation, initial soil water quality, hydraulic conductivity, surface conditions, and profile depth and layering (Hillel, 1998).

All models of infiltration make use of some of those variables to describe infiltration. The more scientifically based calculations, however, depend more heavily on the hydraulic and physical soil properties that occur within the model, such as saturated hydraulic conductivity, gradient of soil moisture, and wetting front suction.

The current study aims to achieve the following objectives:

1.This study aimed at evaluating the influence of different land use types on infiltration characteristics of the soil essential effect of Land Use on Infiltration Characteristics soils of major plains Duhok governorate including (Semel and Zakho) for designing improved soil and water management technologies to reduce soil erosion and for increases in crop production in the study area.

akram.khalaf@uod.ac 
2. To determine the parameters of each of the two models Kostiakov and Philip of the investigated soils. And find out the best suitable model for the two major plains soils under different landuses of mentioned study area.

3. To recommend the best equation to use for each two plain soil type and under different landuses of (CL, FL and $\mathrm{OL})$ for the three studied sites

\section{2 . MATERIALS AND METHODS}

\section{1. Plain selection and description study} sites:

The investigation took place at Duhok governorate including two sites representing three major plains of this region which are Semel, and Zakho. The site locations are shown on the map in Fig.

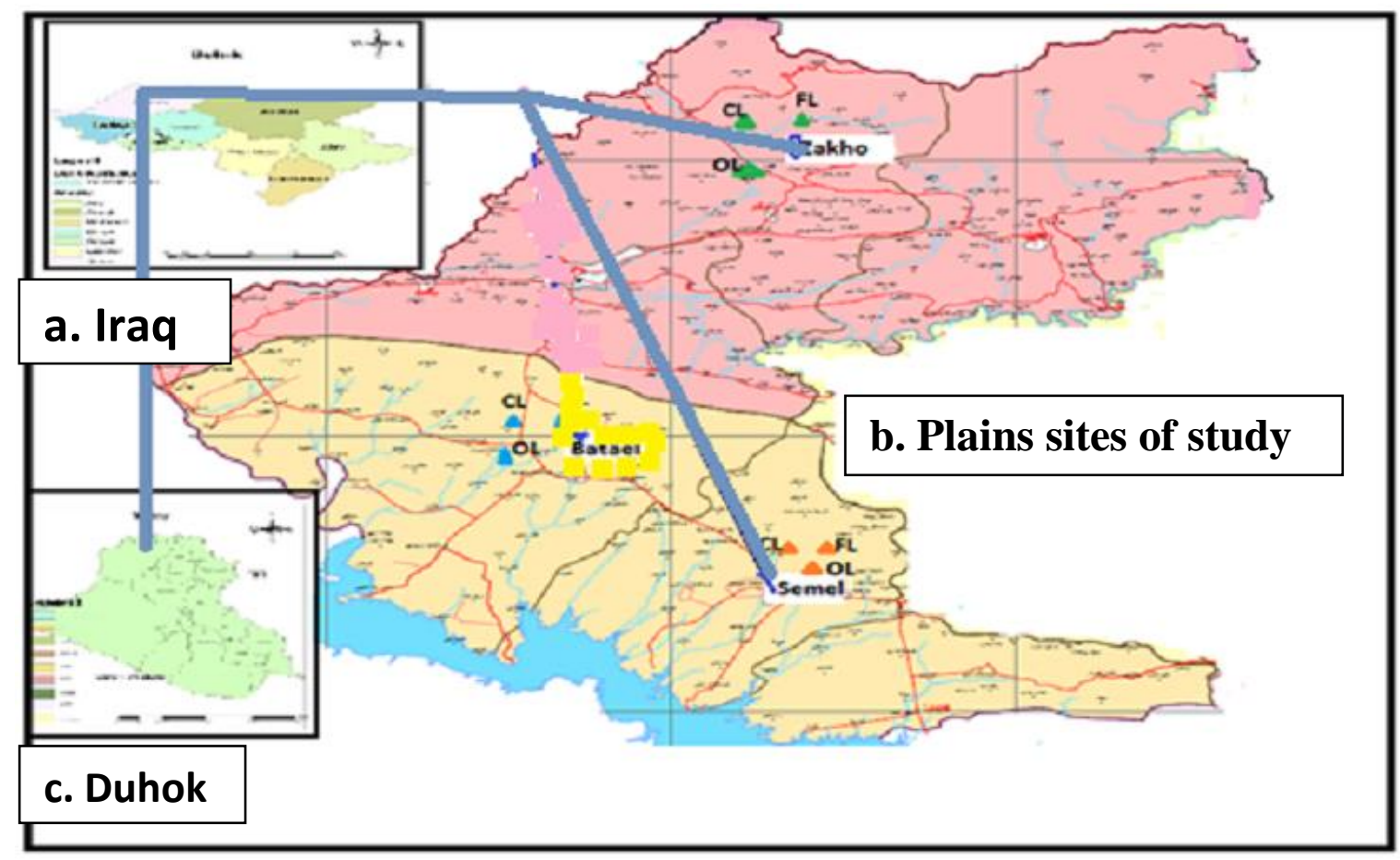

Fig (2.1): Map of Duhok governorate showing the locations of the two study sites.

\subsubsection{Semel Site:}

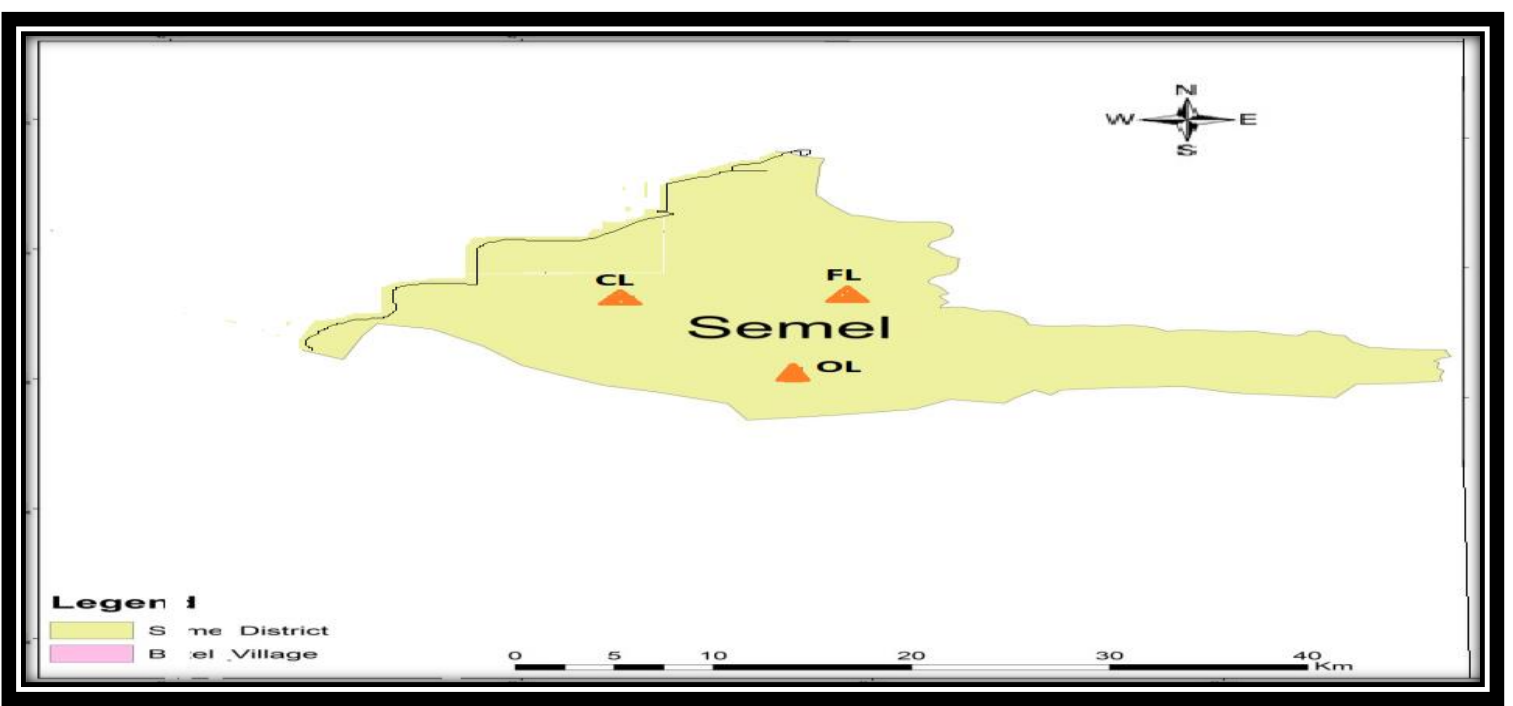

Fig (2.2): Semel site shows locations of three different landuses of CL, FL, and OL

The Semel site situated closes the agricultural engineering sciences college $15 \mathrm{~km}$ west Duhok city at national grid reference (36 $051^{\prime} 40.72^{\prime \prime} \mathrm{N}$ $42^{\circ} 51^{\prime} 27.44^{\prime \prime}$ E) with altitude of 472 meter 
above sea level as Shawn in the fig (2.2). the topography of area is flat with calcareous (limestone) soil bedrock. The soil of area is typical of vertisols and silty clay loam to silty clay soil texture with clay content more than $41 \%$ increasing with depth $30 \mathrm{~cm}$ and also organic $(\mathrm{OM})$ matter content of approximately 1.2-1.8\%, and it represents typical lands of Semel plain. and is considered as deep soils The climate of the area is semi-arid (similar to Mediterranean -type climate) Semel site had a ground cover of sparse vegetation composed of disturbed grass and weeds, and also this site had a slight to dense weedy ground cover.

The annual rainfall average is $535 \mathrm{~mm}$ with unimodal distribution the rainfall season extends from about mid-October to May.

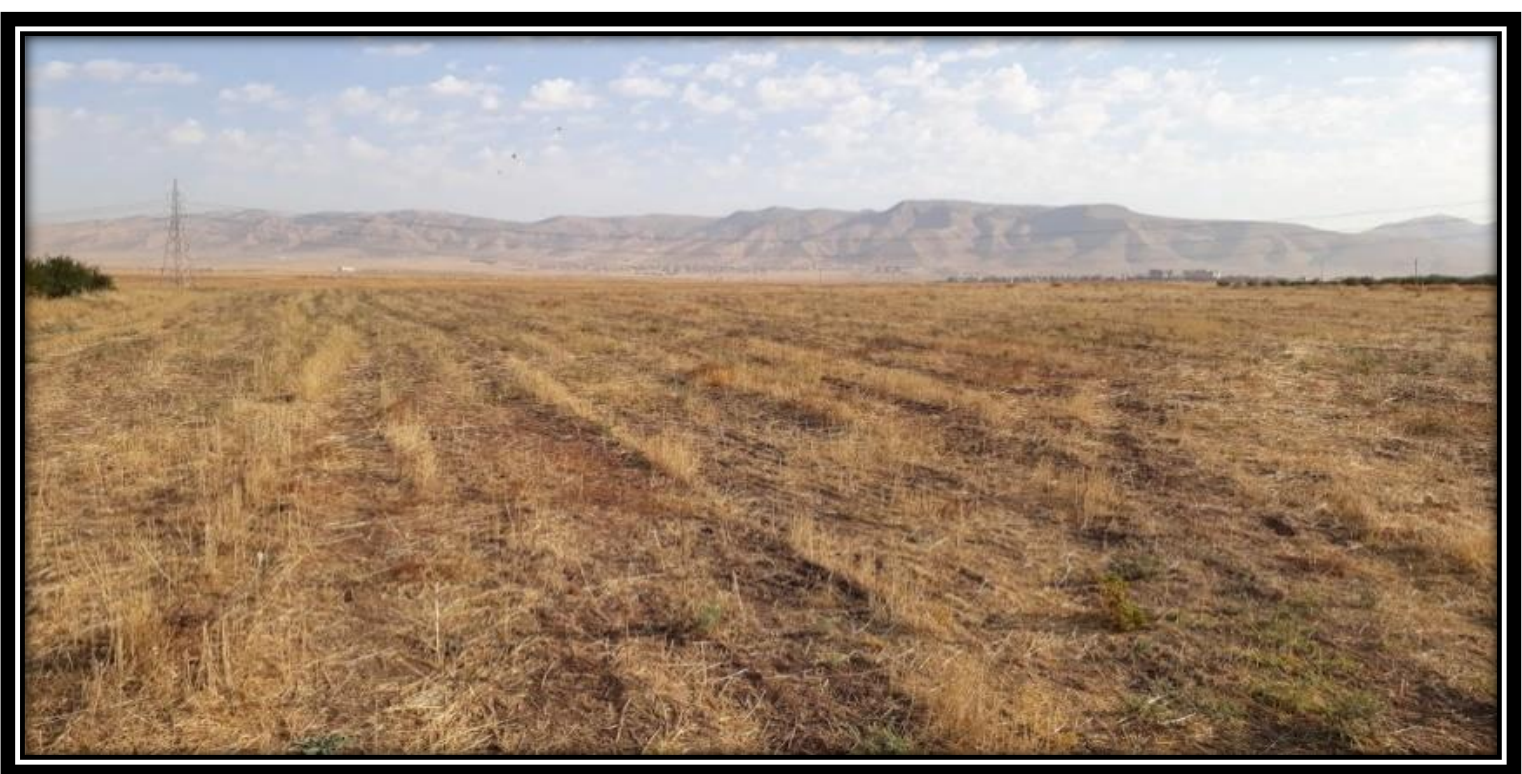

Fig (2.3): General view of Cultivated Land (CL) of Semel site.

Useful to mention that selection Zakho site including three land uses were (Cultivated Land,
CL-Fallow Land, FL, and Orchard Land, OL) as cleared in the fig $(2.3,2.4$, and 2.5$)$ respectively.

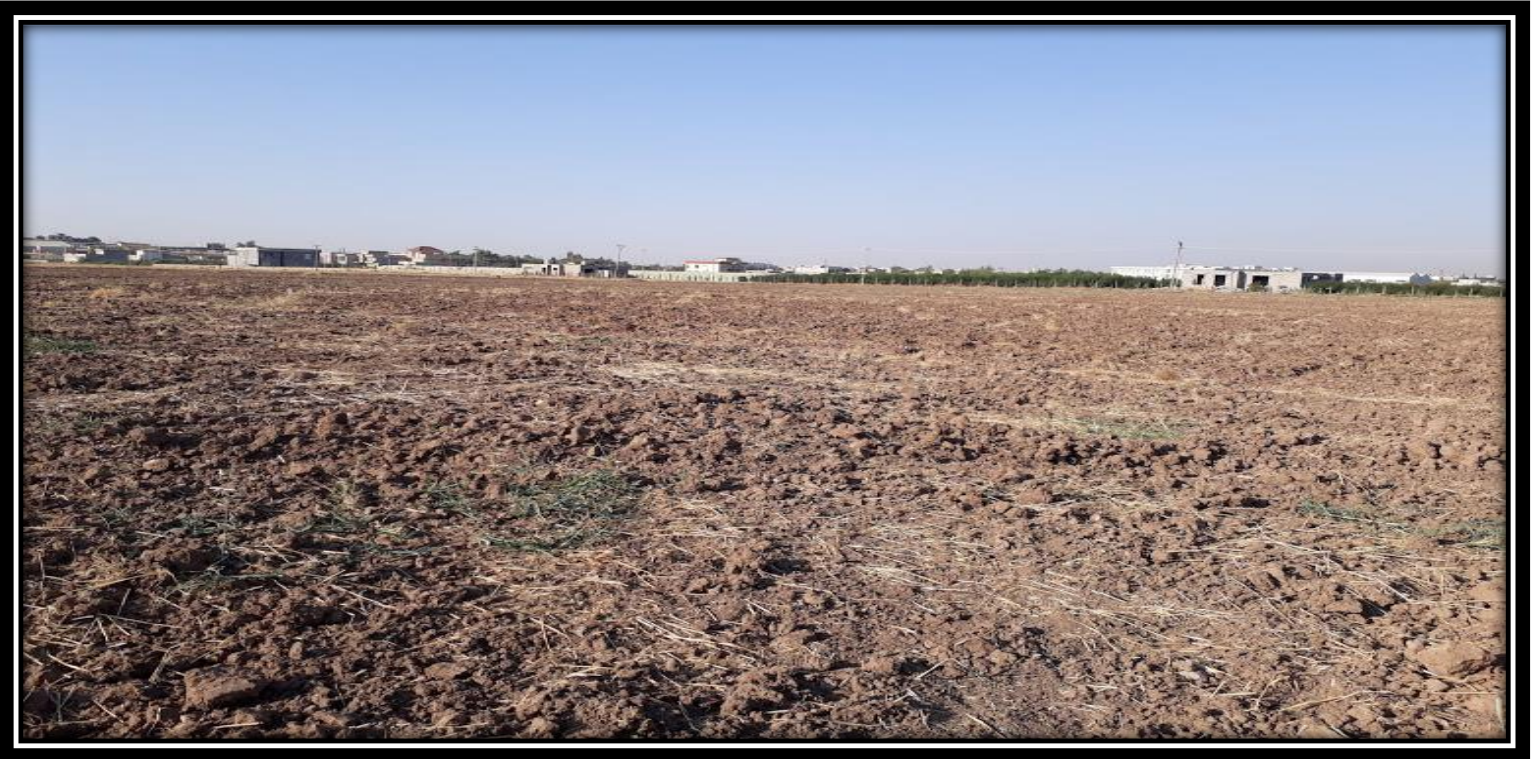

Fig (2.4): General view of Fallow Land (FL) of Semel site. 


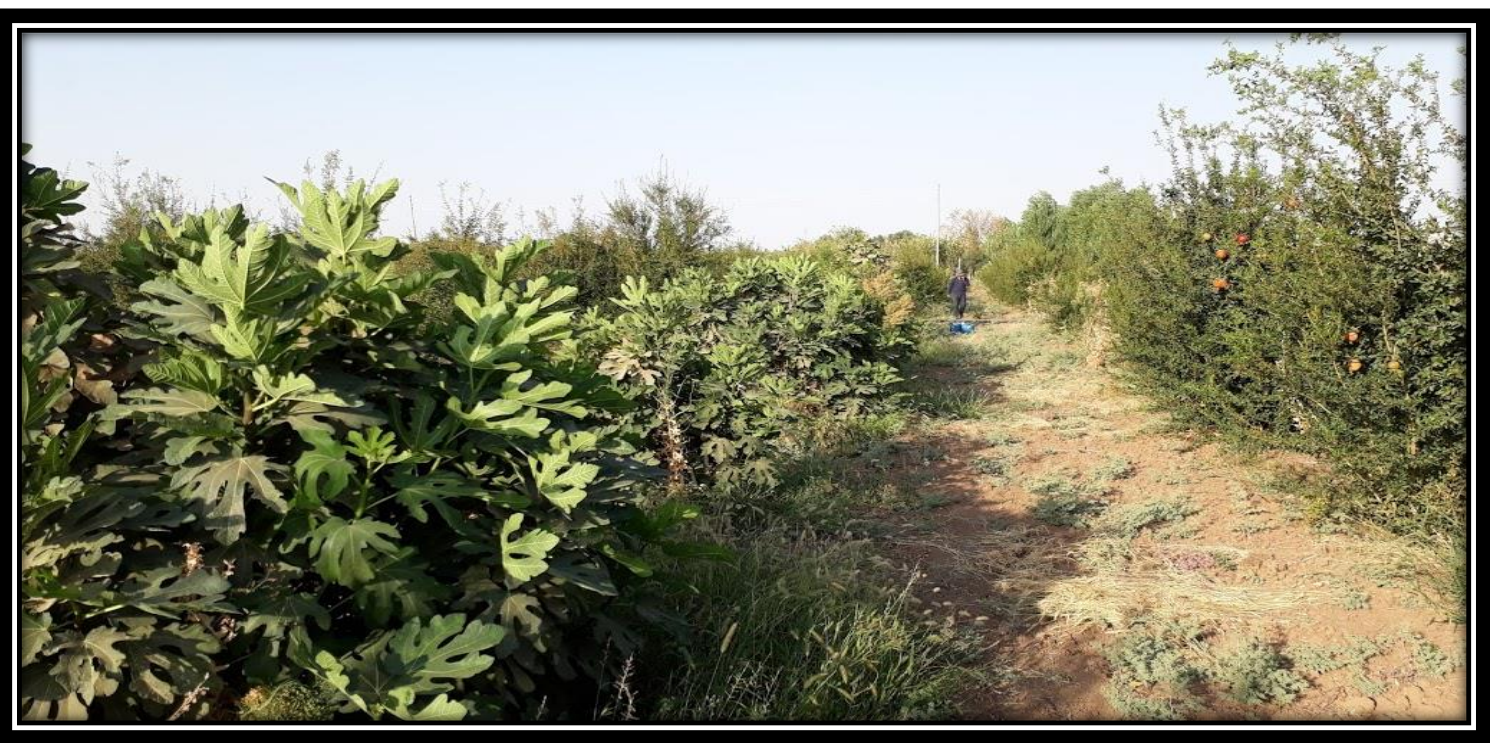

Fig (2.5): General view of Orchard Land (OL) of Semel site.

The previous year and in cultivated land the Wheat, Barley crops, in fallow land the Chick pea and melon crops and in orchard land fruits fig, grape and pomegranate were grown at this site.

\subsubsection{Zakho Site:}

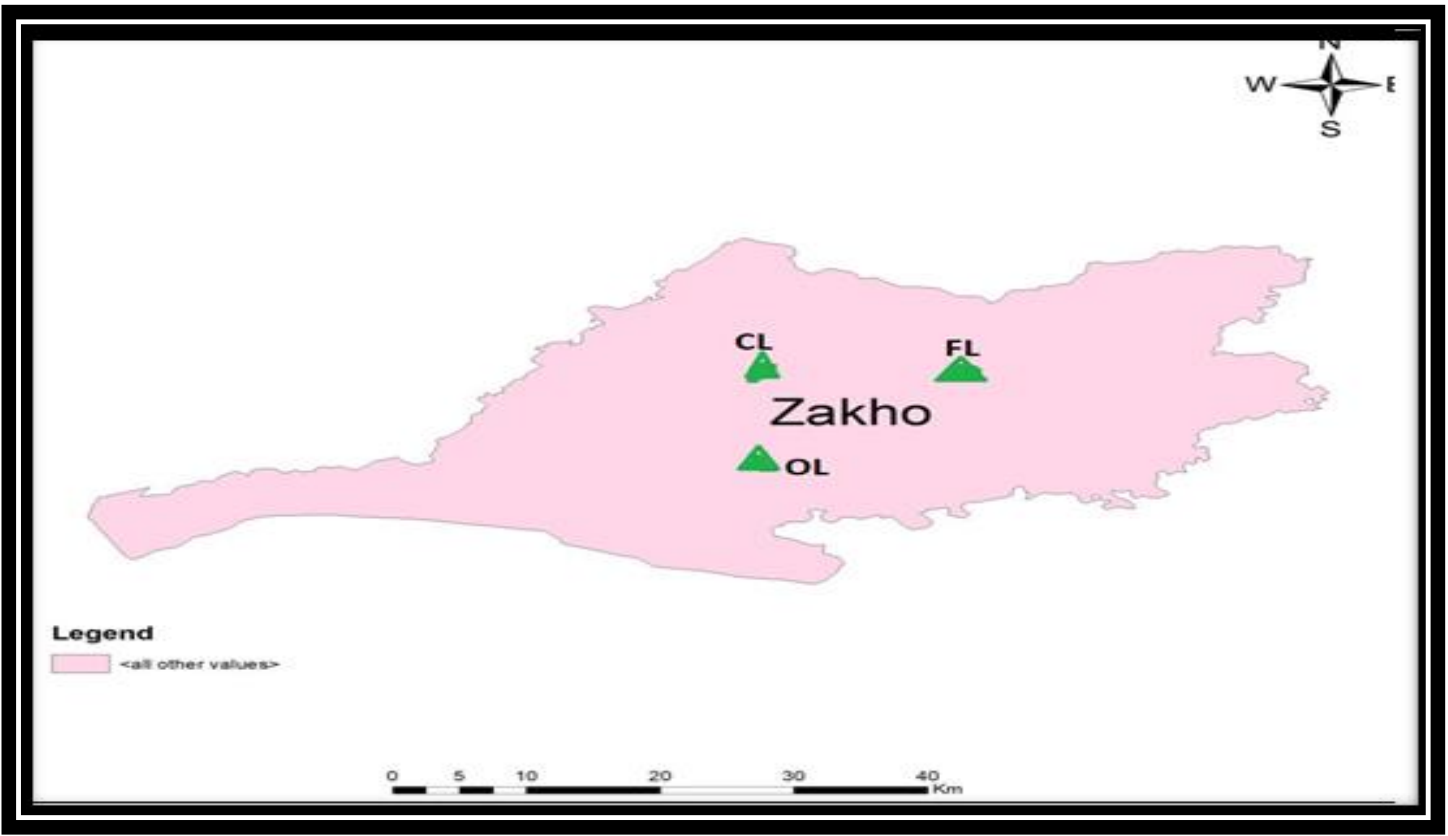

Fig. (2.6): Zakho site shows locations of three different landuses of $\mathrm{CL}, \mathrm{FL}$, and $\mathbf{O L}$

The soils of Zakho site is silty clay to silty loam with about 1-1.5 percent slope and represent atypical soils of Zakho plain, at

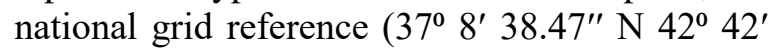
$50.35^{\prime \prime}$ E) with altitude of $\mathbf{4 9 8}$ meter above sea level as Shawn in fig(2.6) . the topography of area is flat with calcareous soil with limestone bedrock. The climate classified as interior Mediterranean of mild winter, dry and hot summer.
The annual rainfall average is $649 \mathrm{~mm}$ with unimodal distribution the rainfall season extends from about mid-October to May.

The Zakho site soils consisted of a moderate deep silty loam to silty clay soils with clay content more than 35\% The Zakho site had a ground cover of sparse vegetation composed of disturbed grass and weeds, and also it is worthy to mention that selection Zakho site including three land uses were (Cultivated Land, CLFallow Land, FL, and Orchard Land, OL) as cleared in the figures $(2.7,2.8$, and 2.9). 


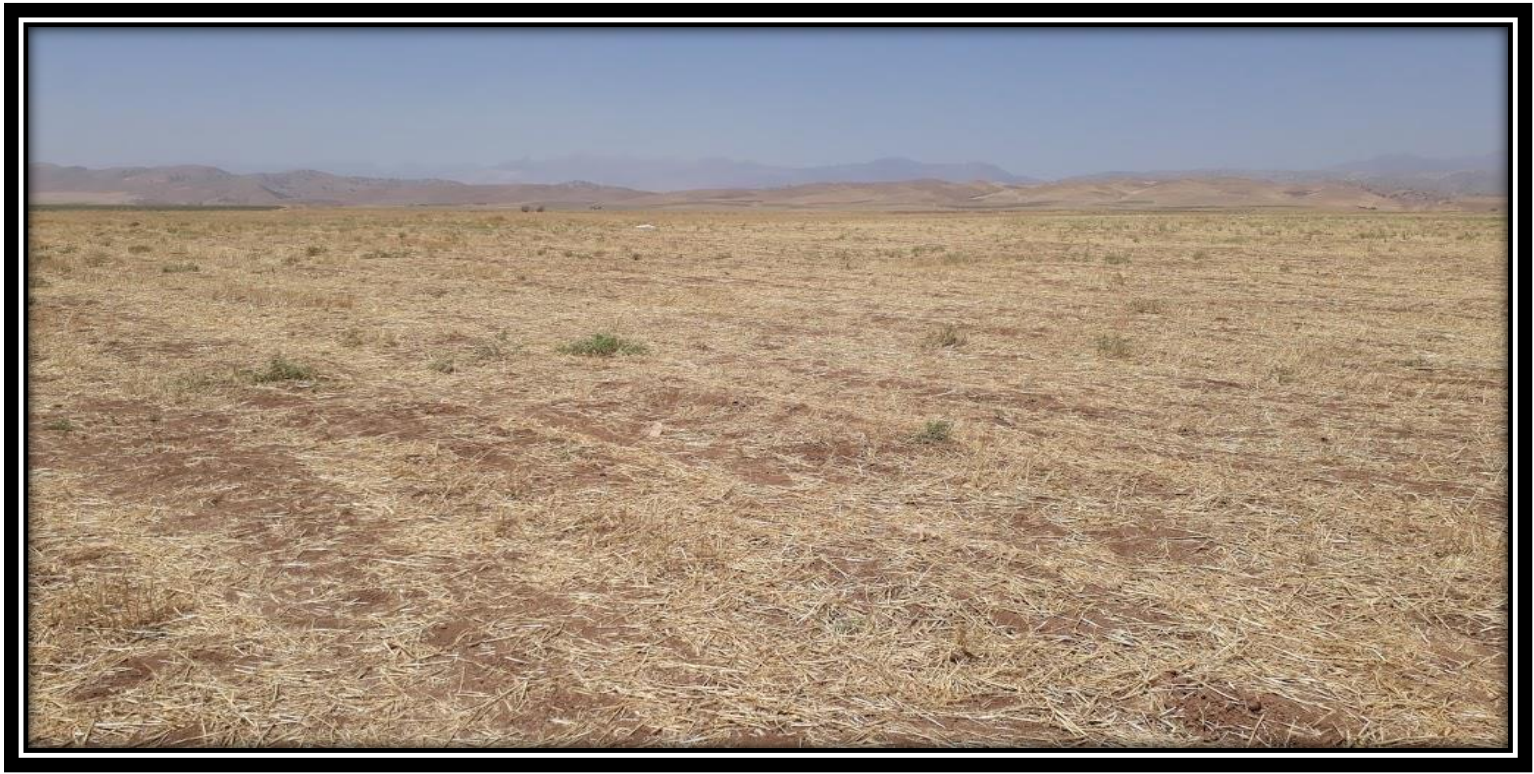

Fig. (2.7): General view of cultivated land of Zakho site.

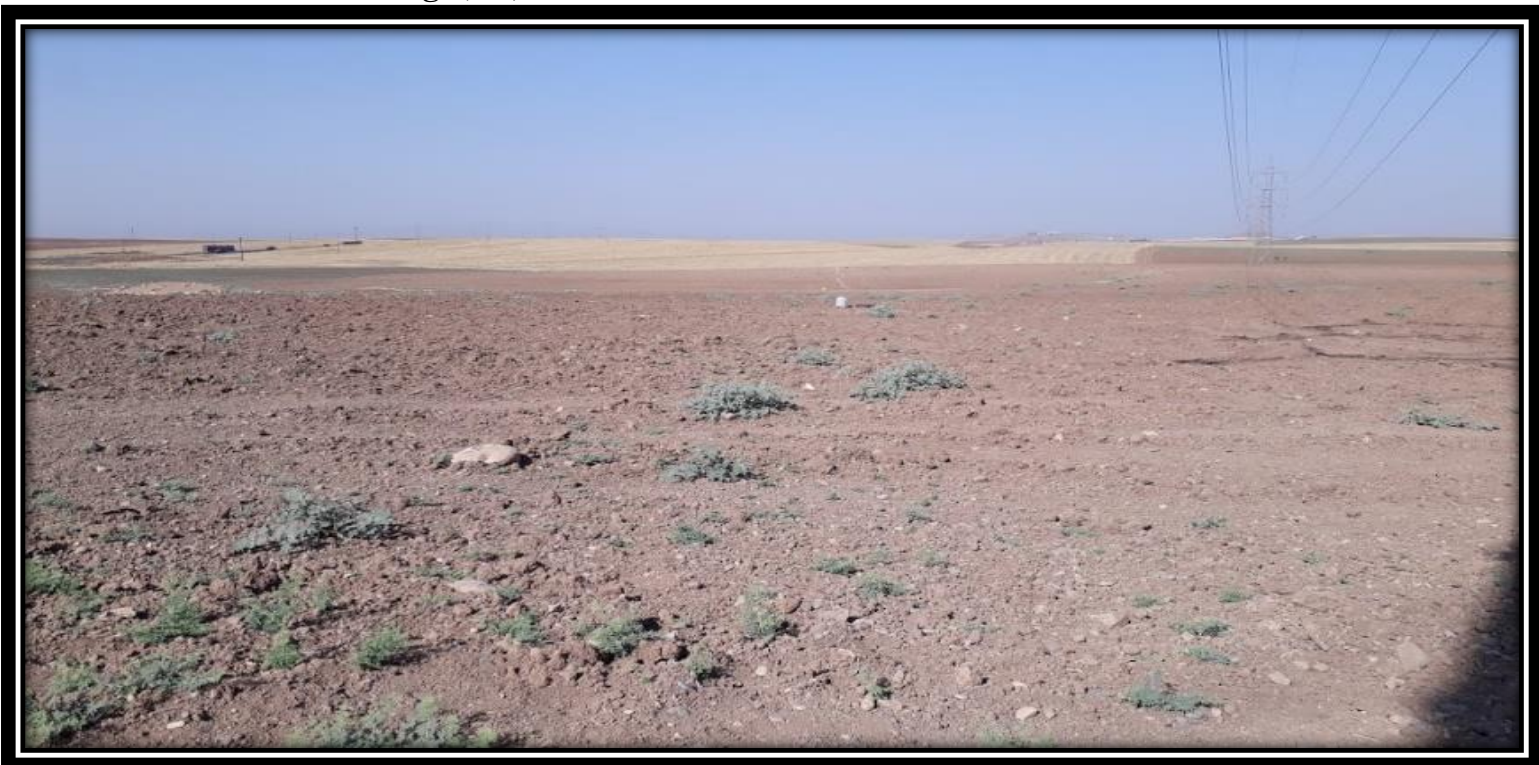

Fig. (2.8): General view of Fallow land of Zakho site.

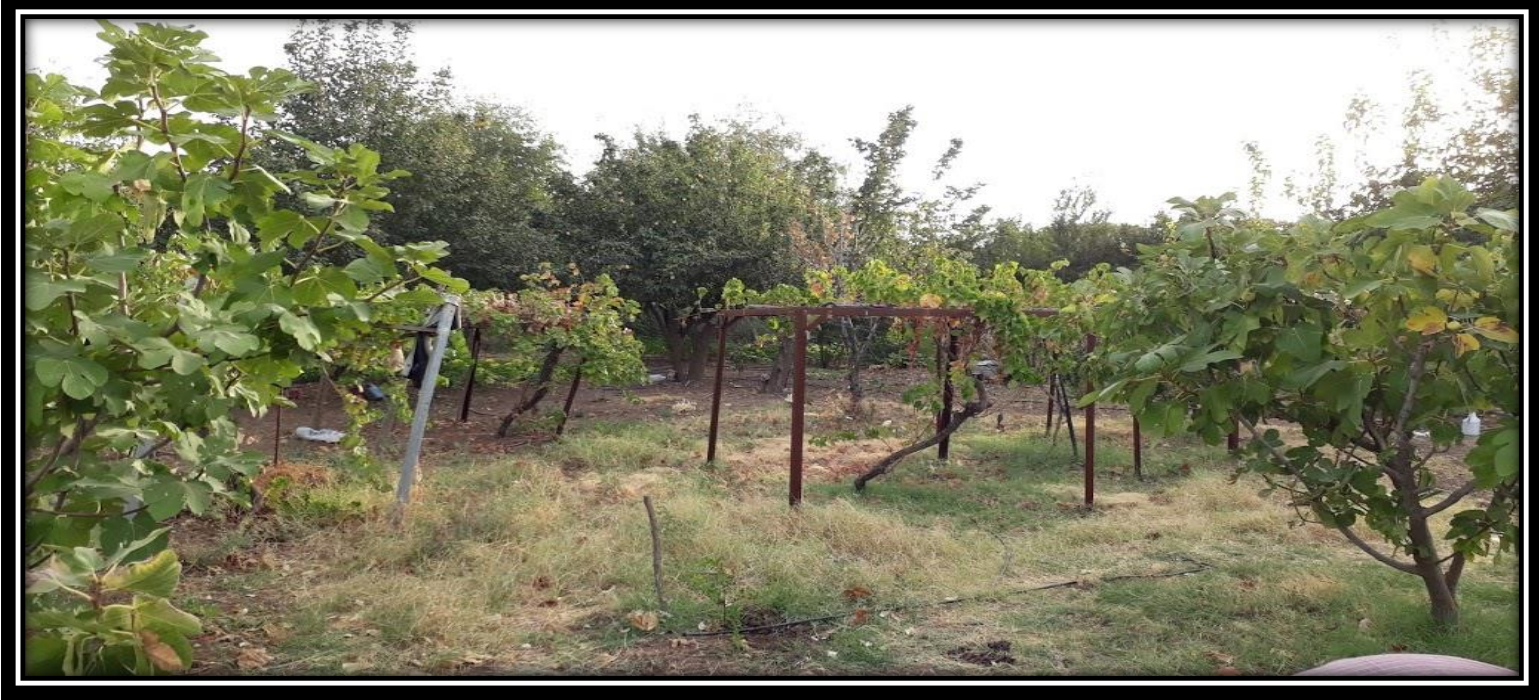

Fig. (2.9): General view of Orchard land of Zakho site.

nechirvan.ahmed@uod.ac; $\quad$ akram.khalaf@uod.ac 


\subsection{Required measurements:}

The two models that will apply which are Kostiakov and Philip these equations require the measurement of the saturated hydraulic conductivity, soil water retention curve, and initial soil water content. Measured Initial soil water content was determined from samples obtained at the field sites immediately, and saturated hydraulic conductivity and soil water retention were determined in the lab from samples obtained at study plains sites.

\subsection{Field experiments:}

\subsubsection{Establishment of grid system:}

A grid system was established over the field for each land use and for each two plains of Semel and Zakho and the infiltration at each grid point. The grid spacing was $200 \mathrm{~m}$ in each direction. The grid system was informed of 3 rows and 3 columns on each land use and for each site (Fig.2.10) the total number of grid points

was

27

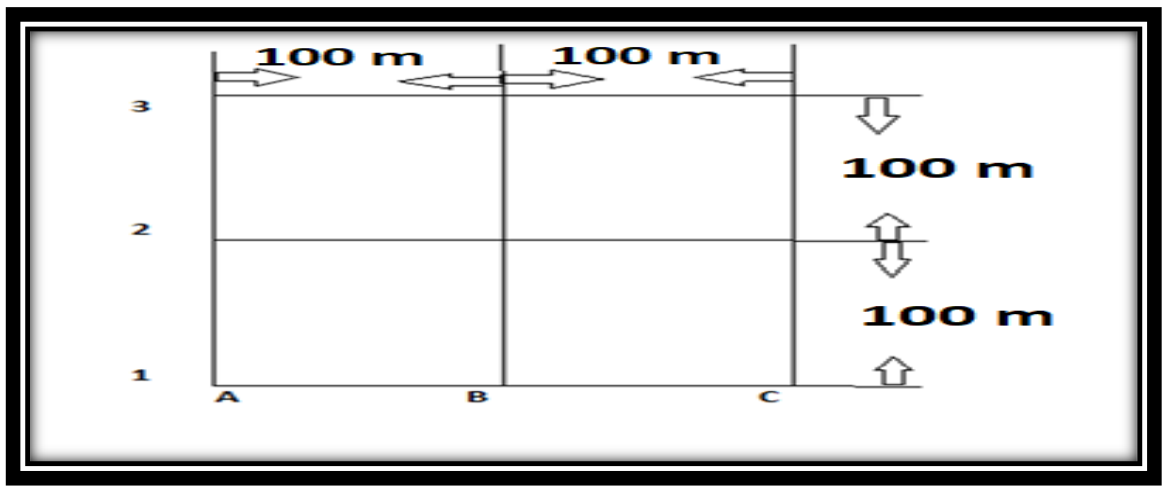

Fig. (2.10): Layout of the grid system for measuring infiltration at Semel experimental site using double ring infiltrometer.

\subsubsection{Apparatus:}

Used three pairs of metal rings .each of them had the different diameters, deeps and with constant roll steel (Gauge 16). The outside rings were 450,450 and $600 \mathrm{~mm}$ in diameter, although the inside rings had the same in diameters were
$300 \mathrm{~mm}$. and used wooden piece or something similar in order to drive the ring in to the soil, hammer, buckets, measuring jug, knife, stopwatch, measuring tape, washcloth and water.

\subsubsection{Measurement of Infiltration rate}

\section{Semel site:}

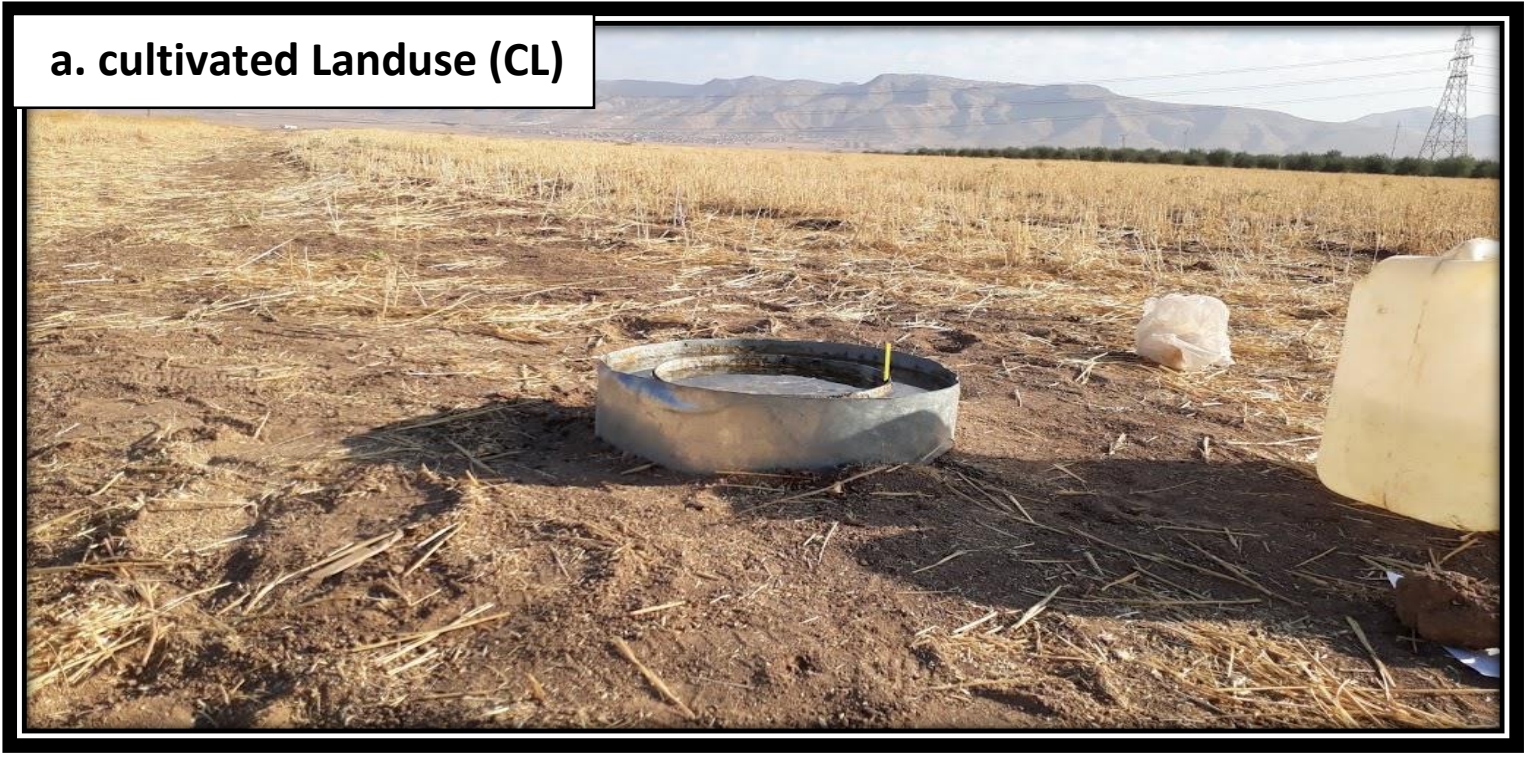



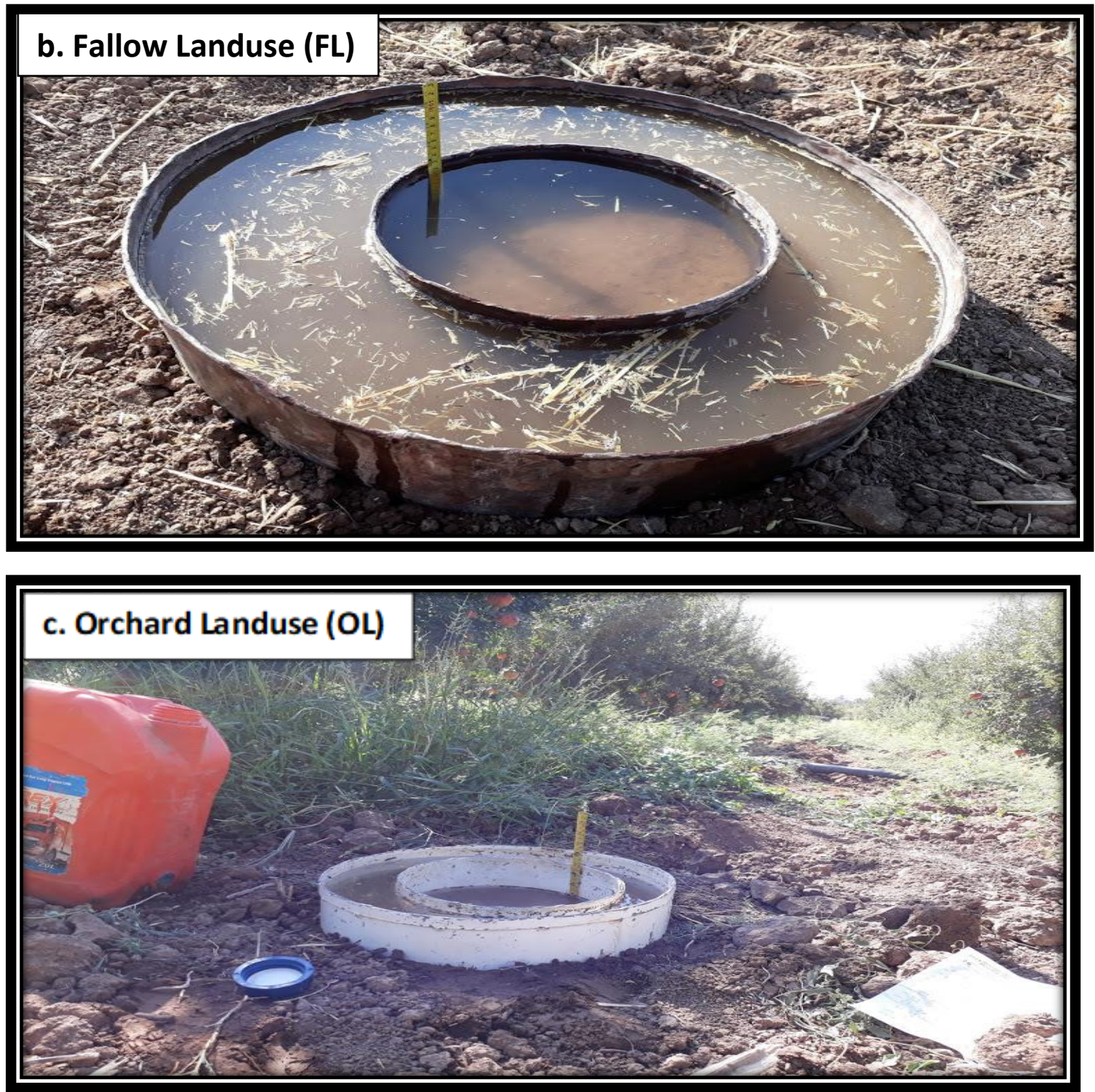

Fig (2.11): Measurement of infiltration rate for Semel site under three different landuses (CL, FL and OL)

\section{Zakho site:}



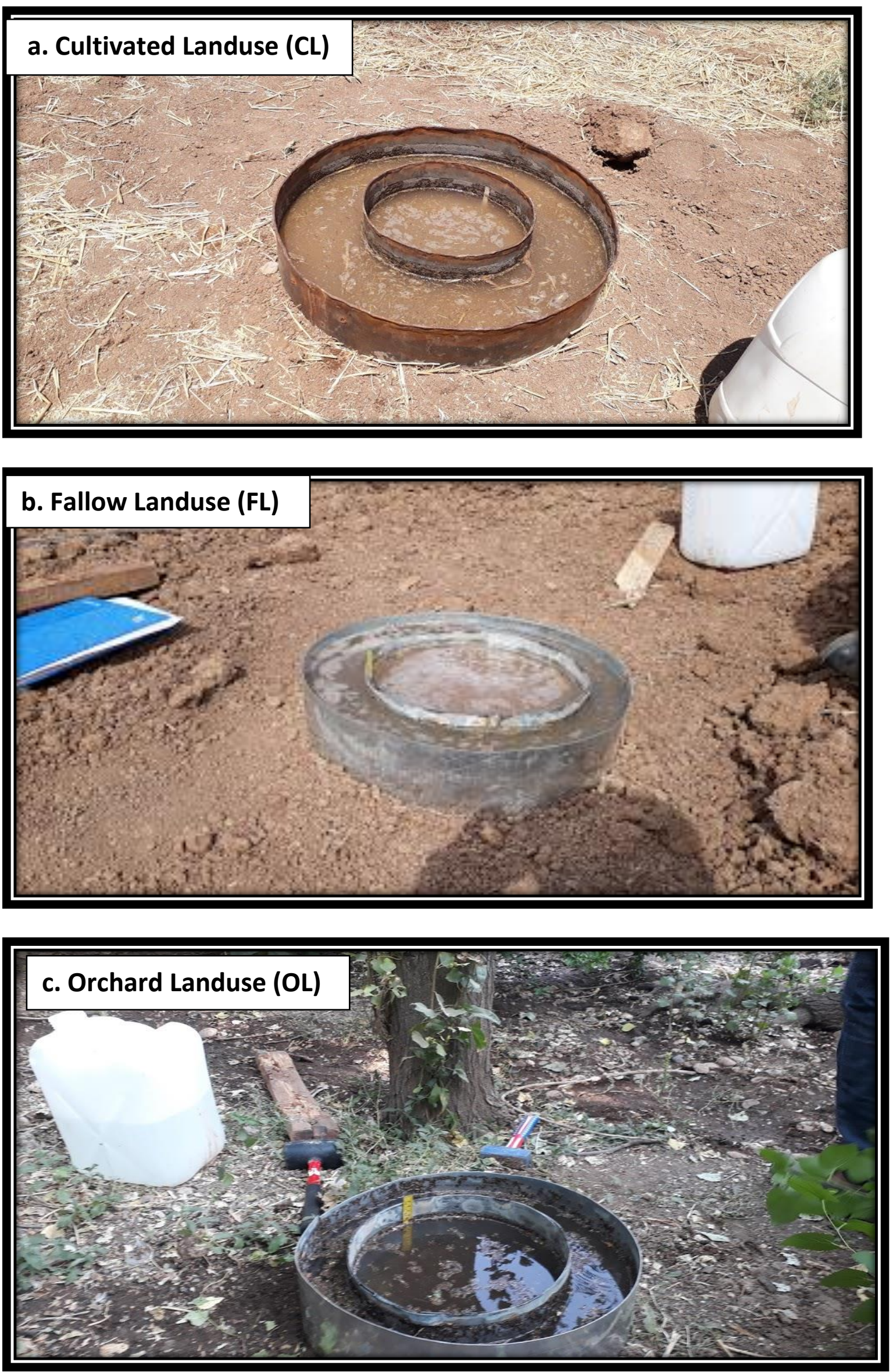

Fig. (2.12): Measurement of infiltration rate for Zakho site under three different landuses (CL, FL and OL). 


\section{4 laboratory measurements:}

\subsubsection{Samples preparation:}

Soil samples from the surface $(0-30 \mathrm{~cm})$ were has been collected at nine points of each land use from two different locations (Semel and Zakho) in Duhok Governorate, from the same site that were used double ring device in it .

\subsubsection{Measurement of saturated hydraulic conductivity:}

To measure saturated hydraulic conductivity the constant-head method was used. Undisturbed soil samples were retained in metal cylinders covered on one end with a piece of cheese cloth that was held in place with a rubber band. The samples were placed covered end down in a tray of water that was filled to a depth just below the top of the samples. The samples were left to soak until saturated, for at least 24 hours (Black et al., 1965) As Shawn in the fig (2.13).

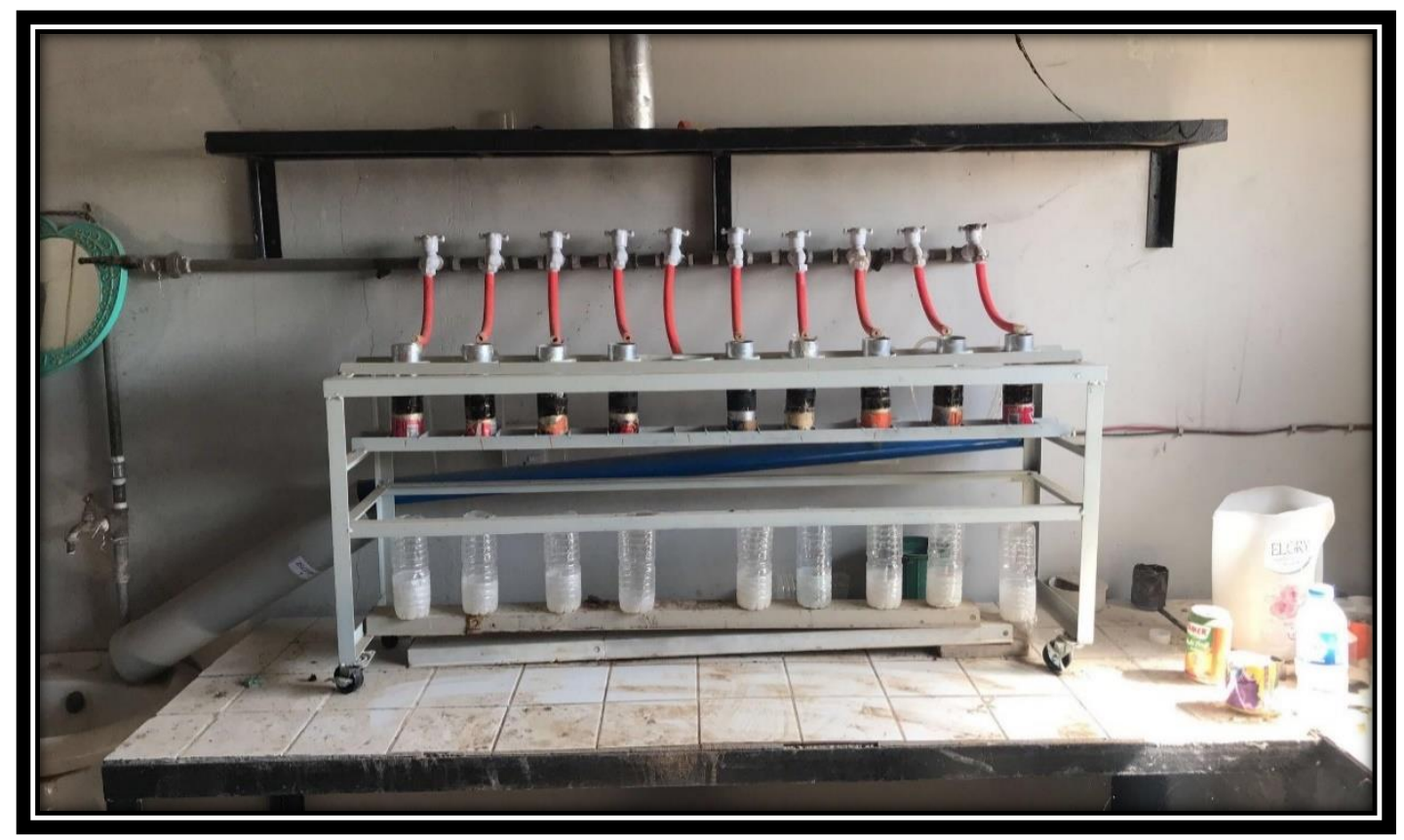

Fig. (2.13): a picture showing the apparatus used for measuring Saturated hydraulic conductivity (HC).

When the samples were saturated, the water supply to the upper trough was turned on. Next, an empty soil cylinder was taped securely the top of each soil-filled cylinder. The lower part of the samples remained immersed in water during these steps. The samples were then transferred to wire screen supports. Glass tubes filled with water with both ends submerged were positioned to siphon water from the trough to the sample. Water slowly filled the upper cylinders from the trough until they were $2 / 3$ to $3 / 4$ full. The samples were then left with water running in at a constant rate for at least an hour until a constant head of water was maintained above the samples. When the water level Fig.(2.14) picture of constant head system for conductivity measurement. According to Black et al., (1965).
Above the samples became stable, the percolate was collected in beakers. The volume of water, V that passed through each sample in a timed interval, $\mathrm{t}$ was measured, as was the hydraulic head, H, (Black et al., 1965). The volume of percolate was collected for five time periods of 4 to 12 minutes for each sample. Saturated hydraulic conductivity is calculated by the equation:

$$
\begin{aligned}
& \mathbf{K s}=\left(\frac{V}{A \Delta t}\right)\left(\frac{L}{H}\right) \\
& \text { or, } \\
& \mathbf{K s}=\left(\frac{Q}{A}\right)\left(\frac{L}{H}\right)
\end{aligned}
$$


$\mathrm{H}=$ the hydraulic head, or height of water above the bottom of soil sample $(\mathrm{cm})$,

$\mathrm{Q}=$ flow rate $=\mathrm{V} / \mathrm{t}\left(\mathrm{ml} \mathrm{min}^{-1}\right)$,

$\mathrm{V}=$ volume of percolate collected $(\mathrm{ml})$, and

$\Delta \mathrm{t}=$ time interval during which percolate was collected ( $\mathrm{min})$.

\subsubsection{Initial volumetric moisture content}

The gravimetric method as described by Gardner (1986) was used to establish initial soil water content for soils samples was determined by the following equation (Gardner, 1986) :

$\theta \mathrm{m}=\frac{((\text { mass wet soil }- \text { mass dry soil }))}{((\text { mass dry soil }))}$

\subsubsection{Bulk density}

Bulk density was calculated by (Gardner, 1986):

$$
\mathrm{pb}=\frac{m s}{V s}
$$

Where is

$\mathrm{pb}=$ bulk density of soil in $\mathrm{g} / \mathrm{cm} 3$

$\mathrm{ms}=$ mass of soil in $\mathrm{g}$

$\mathrm{Vs}=$ volume of soil in $\mathrm{cm} 3$

\subsubsection{Soil Retention Curves,}

The relation between volumetric moisture content $(\theta)$ and tension $(\tau)$ determined by using pressure cooker apparatus for tensions between $(10-500 \mathrm{kpa})$ and pressure plate apparatus for (600 -1500 kpa)

2.5. Evaluation of infiltration models:

2.5.1. Root Mean Square of Error (RMSE)
RMSE $=\sqrt{ } \mathbf{1} / \mathbf{n}$ $\sum_{i=1}^{n}(P i-O i) 2$

(5)

\subsubsection{Coefficient of Residual Mass (CRM) CRM \\ $\frac{\sum_{i=1}^{n}(O i)-\sum_{i=1}^{n}(P i)}{\sum_{i=1}^{n}(O i)}$}

\subsubsection{Coefficient of Determination (R2)}

$$
\mathbf{R}^{2}=\left\{\frac{\sum_{i=1}^{n}(\boldsymbol{O} i-\hat{O})(\boldsymbol{P} i-\dot{\mathrm{P}}) 2}{\sum_{i=1}^{n}(\boldsymbol{O} i-\hat{O}) 2\left(\sum(\boldsymbol{P} i-\dot{\mathrm{P}}) 2\right.}\right\}
$$

Where is:

Oi $=$ observed value

Ỏ = mean of observed values

$\mathrm{Pi}=$ predicted value

$\dot{\mathrm{P}}=$ mean of predicted values.

$\mathrm{n}=$ number of values

\section{Kostiakov model equation}

$\begin{array}{lllll}\text { I } & (\mathbf{t}) \quad & \mathbf{c} & \mathbf{t} & \end{array}$

\section{Where}

I $(\mathrm{t})=$ infiltration rate and $\mathrm{c}, \mathrm{n}$ are Empirical constant

Philip model equation

I $(\mathrm{t}) \quad=\quad \mathrm{St} \quad 1 / 2 \quad+\quad \mathrm{At}$

\section{Where}

$\mathrm{I}(\mathrm{t})=$ infiltration rate

$\mathrm{S}=$ Sorptivity, and $\mathrm{A}=$ Constant it is known as Philips transmissivity term.

\subsection{Analysis of soil properties:}

\subsubsection{Analysis of physical properties:}

\subsubsection{Soil texture:}

Soil texture was determined by two methods international pipet method according to (Day, 1965) stored sample (ISO, 1998) and Hydrometer method fresh taken sample (ISO, 1998) International Standard (ISO) 11277 (1998):

Table (2.1): some physical properties of representative sites under three different land uses for two

\begin{tabular}{|c|c|c|c|c|c|c|c|c|}
\hline \multirow[t]{2}{*}{ Site } & \multirow[t]{2}{*}{ Land use } & \multicolumn{2}{|c|}{ P S D $\quad\left(\mathrm{g} \mathrm{kg}^{-1}\right.$ soil $)$} & & Text, & B D & \multicolumn{2}{|l|}{$\theta m, \%$} \\
\hline & & Sand & Silt & Clay & Class & $\mathrm{Mg} \mathrm{m}^{-3}$ & $33 \mathrm{kpa}$ & $1500 \mathrm{kpa}$ \\
\hline \multirow[t]{3}{*}{ Semel } & $\overline{C L}$ & 78.38 & 550.86 & 370.76 & SiCL & 1.371 & 39.92 & 17.27 \\
\hline & FL & 43.19 & 505.26 & 451.55 & SiC & 1.353 & 40.25 & 19.30 \\
\hline & OL & 35.02 & 444.55 & 520.43 & SiC & 1.304 & 41.37 & 19.95 \\
\hline \multirow[t]{3}{*}{ Zakho } & $\overline{C L}$ & 37.04 & 478.89 & 460.25 & SiC & 1.490 & 42.03 & 21.51 \\
\hline & FL & 60.86 & 497.89 & 441.25 & SiC & 1.344 & 42.30 & 20.51 \\
\hline & OL & 158.9 & 637.01 & 204.10 & SiL & 1.226 & 41.03 & 26.36 \\
\hline
\end{tabular}
major plains of Duhok govern-orate. 
2.6.2. Chemical analysis of soils:

The $\mathrm{pH}$ of saturation extract was measured by using $\mathrm{pH}-$ meter according to Jackson (1958).Electrical conductivity of the saturated soil extract (ECe) was measured according to Walkely and Black as mentioned in Jackson (1958).and soil content of calcium carbonate determined as described method in Page (182),tables (1,2) results of physical and chemical

Table (2.2): some chemical properties of representative sites under three different land uses for two major

\begin{tabular}{|c|c|c|c|c|c|}
\hline Site & Land use & $\mathrm{pH}$ & Ec & O.M & $\mathrm{CaCO}_{3}$ \\
\hline & & ext.1:1 & $\mathrm{dSm}^{-1}$ & $\mathrm{~g} \mathrm{~kg}^{-1}$ & $\mathrm{~g} \mathrm{~kg}^{-1}$ \\
\hline \multirow[t]{3}{*}{ Semel } & CL & 7.82 & 0.75 & 18.6 & 301.3 \\
\hline & FL & 8.12 & 0.61 & 15.2 & 2662 \\
\hline & OL & 7.43 & 0.46 & 12.4 & 178.4 \\
\hline \multirow[t]{3}{*}{ Zakho } & CL & 7.78 & 0.82 & 15.9 & 241.3 \\
\hline & $\overline{F L}$ & 7.42 & 0.64 & 14.8 & 219.6 \\
\hline & $\overline{O L}$ & 8.05 & 0.37 & 12.7 & 207.1 \\
\hline
\end{tabular}

Duhok governorate.

\subsubsection{Data analysis}

Microsoft Excel (2010) was used to determine the correlation between some selected and dependent and independent variables. Statistica version (10) was used to analyze the data. And to obtain the parameters of three infiltration models which were (Kostiakov, and Philip) and the surfer software (16) was used to subdivide the field of two different sites represents two major plains of Duhok governate (Semel, and Zakho) under different landuses

\section{RESULTS AND DISCUSSIONS}

\subsection{Determination of parameters:}

\subsubsection{Kostiakov equation:}

\subsubsection{Semel Site:}

The data which employed for this analysis is derived from conducting 81 infiltration tests in the field under different textures of soil, different soil moisture content and bulk densities. Table (3.1) shows the optimal parameters values of Kostiakov model for the measured under three different landuses for Semel site (cultivated, fallow and orchard) field data, it can be noticed that the parameter of Kostiakov model (Cparameter varies from a minimum of 1.862 from the fallow land silty clay to the maximum of 4.677 from orchard land silty clay.

While the n-parameter of Kostiakov model ranges from a lowest value of 0.416 from orchard landuse to the highest value of 0.833 from cultivated landuse. And the remains values of n-Kostiakov parameter being intermediate between two these extremes values.

The soil bulk density varied from a minimum value of $1.21 \mathrm{Mg} \mathrm{m}^{-3}$ to $1.49 \mathrm{Mg} \mathrm{m}-3$ of maximum value obtained under same landuse of FL. and soil moisture content ranged from $5.662 \%$ to $18.531 \%$ from each landuse of CL and OL respectively, Furthermore the results also showed that the saturated hydraulic conductivity differed from the lowest value of $0.129 \mathrm{~cm} / \mathrm{hr}$ for CL to the highest value of 6.336 $\mathrm{cm} / \mathrm{hr}$ for FL and the remaining values were intermediate between these two-extreme values. 
Table (3.1): Saturated hydraulic conductivity and parameters of Kostiakov equation obtained by logarithmic method for Semel site under three different landuses at different levels of initial soil moisture and bulk density.

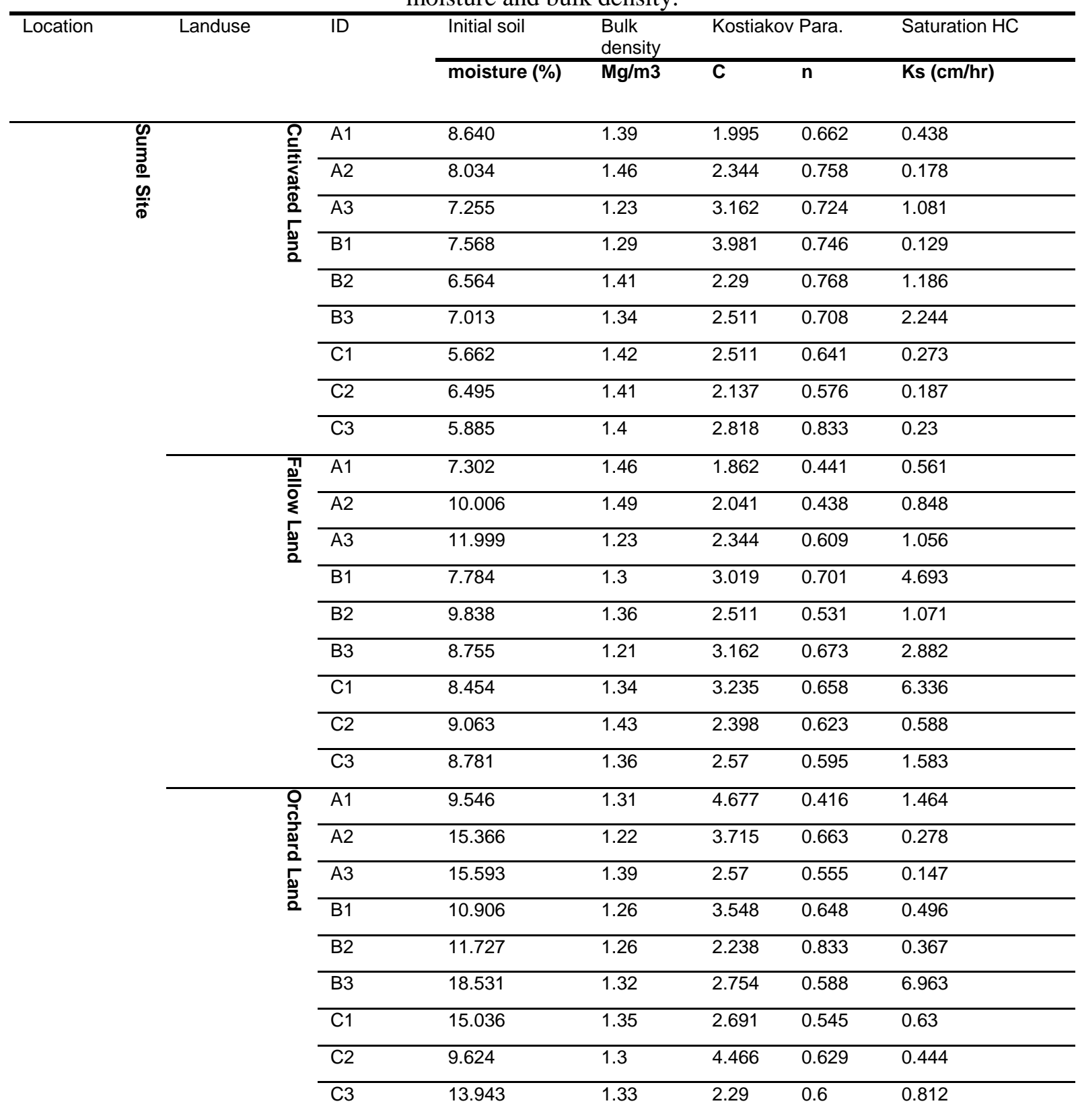

\subsubsection{Zakho Site:}

It can be seen from table (3.2) the optimal Kostiakov parameters of three different land use (Cultivate, Fallow and Orchard) from Zakho Site under different soil density and moisture content, the results shown that the Kostiakov model Cparameter varies from a minimum value of 1.445 from orchard land silty clay to the maximum of 12.302 from fallow land silty clay On the other hand, the n- parameter of Kostiakov model values ranged from a minimum of 0.351 from fallow land silty clay to the maximum of 0.923 of the same landuse whereas the values of
Kostiakov C-parameter ranged between 1.445 for OL to 12.302 for FL landuses.

The soil bulk density value of each point ranged from lowest to highest it ranges between $1.05 \mathrm{Mg} \mathrm{m}^{-3}$ for $\mathrm{OL}$ to $1.66 \mathrm{Mg} \mathrm{m}^{-3}$ for $\mathrm{CL}$, while the initial soil moisture content varied from $0.066 \%$ for CL to $33.6407 \%$.for landuse of CL, Furthermore the saturated hydraulic conductivity was $0.0773 \mathrm{~cm} / \mathrm{hr}$ to $4.5 \mathrm{~cm} / \mathrm{hr}$.for same landuse of OL the remaining values of Kostiakov model-parameter intermediate between two extreme values. 
Table (3.2): Saturated hydraulic conductivity and parameters of Kostiakov equation obtained by logarithmic method for Zakho Site under three different landuse at different levels of initial soil moisture and bulk density.

\begin{tabular}{|c|c|c|c|c|c|c|c|c|}
\hline \multirow[t]{2}{*}{ Location } & \multirow{2}{*}{\multicolumn{2}{|c|}{ Landuse }} & \multirow[t]{2}{*}{ ID } & \multirow{2}{*}{$\begin{array}{l}\text { Initial Soil } \\
\text { Moisture (\%) }\end{array}$} & \multirow{2}{*}{$\begin{array}{l}\text { Bulk } \\
\text { density } \\
\mathbf{M g} / \mathbf{m 3}\end{array}$} & \multicolumn{2}{|l|}{$\begin{array}{l}\text { Kostiakov } \\
\text { Para. }\end{array}$} & \multirow[t]{2}{*}{ Saturation $\mathrm{HC}$} \\
\hline & & & & & & C & $\mathbf{n}$ & \\
\hline \multirow{27}{*}{$\begin{array}{l}\mathbf{N} \\
\text { N } \\
\frac{\pi}{\overrightarrow{0}} \\
0 \\
\frac{N}{\vec{D}}\end{array}$} & & $\stackrel{\rho}{\varrho}$ & $\mathrm{A} 1$ & 0.066 & 1.28 & 4.57 & 0.687 & 0.394 \\
\hline & & ఏ & $\mathrm{A} 2$ & 0.095 & 1.66 & 1.908 & 0.606 & 0.204 \\
\hline & & $\frac{a}{r}$ & A3 & 0.079 & 1.32 & 5.248 & 0.600 & 0.285 \\
\hline & & בั้ & $\mathrm{B} 1$ & 0.114 & 1.59 & 2.63 & 0.736 & 1.037 \\
\hline & & & B2 & 0.092 & 1.40 & 3.162 & 0.784 & 0.509 \\
\hline & & & B3 & 0.106 & 1.55 & 5.248 & 0.480 & 0.441 \\
\hline & & & $\mathrm{C} 1$ & 0.092 & 1.52 & 2.238 & 0.703 & 0.124 \\
\hline & & & $\mathrm{C} 2$ & 0.067 & 1.54 & 5.011 & 0.642 & 1.316 \\
\hline & & & C3 & 0.123 & 1.55 & 1.778 & 0.49 & 0.141 \\
\hline & & 刃 & $\overline{\mathrm{A} 1}$ & 13.783 & 1.55 & 12.302 & 0.351 & 0.174 \\
\hline & & $\stackrel{\circ}{\Sigma}$ & $\mathrm{A} 2$ & 13.393 & 1.46 & 7.079 & 0.361 & 0.226 \\
\hline & & כ) & A3 & 7.657 & 1.46 & 3.99 & 0.431 & 0.148 \\
\hline & & & B1 & 5.940 & 1.24 & 11.481 & 0.549 & 0.145 \\
\hline & & & B2 & 6.733 & 1.13 & 5.623 & 0.701 & 0.129 \\
\hline & & & B3 & 5.940 & 1.38 & 3.89 & 0.923 & 0.45 \\
\hline & & & $\mathrm{C} 1$ & 8.227 & 1.15 & 4.073 & 0.714 & 0.096 \\
\hline & & & $\mathrm{C} 2$ & 20.947 & 1.4 & 2.951 & 0.53 & 0.382 \\
\hline & & & C3 & 8.780 & 1.33 & 7.762 & 0.385 & 0.149 \\
\hline & & 움 & $\overline{A 1}$ & 32.980 & 1.43 & 2.951 & 0.619 & 0.418 \\
\hline & & ฐ & $\mathrm{A} 2$ & 23.620 & 1.06 & 2.754 & 0.569 & 4.500 \\
\hline & & 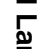 & A3 & 8.407 & 1.27 & 3.09 & 0.836 & 0.296 \\
\hline & & $a$ & B1 & 33.647 & 1.1 & 4.897 & 0.52 & 0.099 \\
\hline & & & B2 & 15.403 & 1.39 & 7.585 & 0.622 & 0.463 \\
\hline & & & B3 & 22.690 & 1.22 & 7.762 & 0.457 & 0.411 \\
\hline & & & $\mathrm{C} 1$ & 25.700 & 1.21 & 1.445 & 0.397 & 0.873 \\
\hline & & & $\mathrm{C} 2$ & 14.063 & 1.05 & 3.388 & 0.471 & 0.077 \\
\hline & & & C3 & 26.330 & 1.3 & 3.548 & 0.458 & 2.615 \\
\hline
\end{tabular}

\subsubsection{The comparison between Kostiakov} model $\mathbf{C}$, $n$ parameters for two sites under different landuses:

To study the comparison between the infiltration parameters of the Kostiakov equation, the minimum value of C-parameter was located in Zakho site (orchard landuse) (Table 3.2), While the maximum value of $\mathrm{C}$ parameter was situated in Zakho site (Fallow landuse) whereas the less value of n-parameter was placed in Zakho site, and the high value of n-parameter was located in Zakho site under same landuse of (Fallow landuse). Therefore the results also showed that the saturated hydraulic conductivity had a low value in Zakho site (orchard landuse) (Table 3.2) and had a maximum value in Semel site (Fallow landuse).

The results of the infiltration tests in the field of present study quite similar with the research results of; Turner (2006), Amin (2008), Igbadun H. E., et al (2016) Parveen Sihag, et al (2017) Utin and Oguike (2018); and Nugroho Suryoputro, et al (2018).

akram.khalaf@uod.ac 


\subsubsection{Philip equation:}

\subsubsection{Semel Site:}

Table (3.3) demonstrated that optimum parameters of Philip equation from Semel site under three different landuses. Table (3.3) revealed that Philip sorptivity term(S) exhibit a lowest value in cultivated landuse silty clay loam $7.491 \mathrm{~cm} \cdot \mathrm{t}^{-1 / 2,}$ While the highest value in orchard landuse silty clay $21.762 \mathrm{~cm} . \mathrm{t}^{-1 / 2}$. and the remaining value were intermediate between two extremes. But the transmissivity term of Philip equation was a minimum value in cultivated landuse with texture of silty clay loam, CL $0.04257 \mathrm{~cm} \mathrm{hr}^{-1}$ although the maximum values of Philip transmissivity term was $2.29779 \mathrm{~cm} \mathrm{hr}$ ${ }^{-1}$ from orchard land silty clay, and the others test value was intermediate between two extreme values.

Table (3.3): Parameters of Philip's equation obtained for Semel Site under three different landuses:

\begin{tabular}{|c|c|c|c|c|c|c|}
\hline Location & & Land use & & ID & $\underbrace{\text { S Sorptivity } \mathrm{cm} . \mathrm{t}}_{-1 / 2}$ & $\begin{array}{l}\text { A (Transmissivity) }(0.33 \mathrm{Ks} \\
\mathrm{HC})\end{array}$ \\
\hline \multirow{18}{*}{\multicolumn{2}{|c|}{ 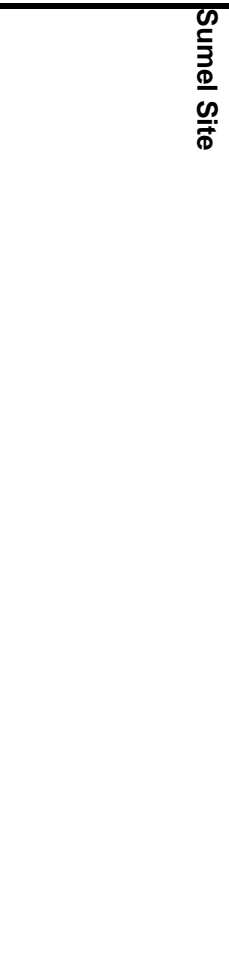 }} & & \multirow{9}{*}{ 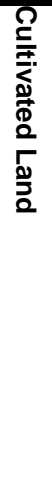 } & $\overline{A 1}$ & 10.836 & 0.14454 \\
\hline & & & & A2 & 9.163 & 0.05874 \\
\hline & & & & A3 & 7.491 & 0.35673 \\
\hline & & & & B1 & 11.313 & 0.04257 \\
\hline & & & & B2 & 10.354 & 0.39138 \\
\hline & & & & B3 & 9.396 & 0.74052 \\
\hline & & & & C1 & 11.791 & 0.09009 \\
\hline & & & & C2 & 11.546 & 0.06171 \\
\hline & & & & C3 & 11.301 & 0.0759 \\
\hline & & & \multirow{9}{*}{ 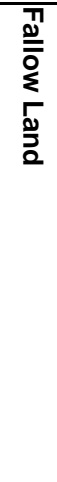 } & $\overline{A 1}$ & 16.016 & 0.18513 \\
\hline & & & & $\overline{A 2}$ & 18.773 & 0.27984 \\
\hline & & & & A3 & 21.531 & 0.34848 \\
\hline & & & & B1 & 16.21 & 1.54869 \\
\hline & & & & B2 & 17.471 & 0.35343 \\
\hline & & & & B3 & 18.734 & 0.95106 \\
\hline & & & & C1 & 16.404 & 2.09088 \\
\hline & & & & C2 & 16.17 & 0.19404 \\
\hline & & & & C3 & 15.937 & 0.52239 \\
\hline & & & \multirow{9}{*}{$\begin{array}{l}\text { 음 } \\
\frac{1}{3} \\
\frac{0}{2} \\
\frac{0}{2} \\
\frac{2}{3} \\
2\end{array}$} & $\overline{\mathrm{A} 1}$ & 19.706 & 0.48312 \\
\hline & & & & $\overline{A 2}$ & 18.972 & 0.09174 \\
\hline & & & & A3 & 18.238 & 0.04851 \\
\hline & & & & B1 & 20.734 & 0.16368 \\
\hline & & & & B2 & 19.825 & 0.12111 \\
\hline & & & & B3 & 18.917 & 2.29779 \\
\hline & & & & C1 & 21.762 & 0.2079 \\
\hline & & & & C2 & 20.679 & 0.14652 \\
\hline & & & & C3 & 19.597 & 0.26796 \\
\hline
\end{tabular}

\subsubsection{Zakho Site:}

]The results of table(3.4) shows the parameters of Philip model for Zakho site under three different landuses, it should be mentioned that the lowest value of sorptivity term of Philip model was located in orchard landuse silty loam $3.629 \mathrm{~cm} \mathrm{t}^{-1 / 2}$ and the greatest value was also placed in orchard landuse silty loam $10.286 \mathrm{~cm} \mathrm{t}$ 
${ }^{-1 / 2}$,whereas the greatest value of transmissivity 1.485 was also noticed in OL, and minimum value of 0.025 obtained also in $\mathrm{OL}$ and the remaining values of sorptivity term were intermediate between these two extremes,

Table (3.4): Parameters of Philip's equation obtained for Zakho site under three different landuses

\begin{tabular}{|c|c|c|c|c|c|c|}
\hline Location & & Land use & & ID & $\begin{array}{l}\text { S } \\
\text { Sorptivity } \mathrm{cm} \cdot \mathrm{t}^{1 / 2}\end{array}$ & $\begin{array}{l}\text { A } \\
\text { (Transmissivity) } \\
1 / 3 \mathrm{Ks}(\mathrm{cm} / \mathrm{hr})\end{array}$ \\
\hline \multirow{18}{*}{\multicolumn{2}{|c|}{ 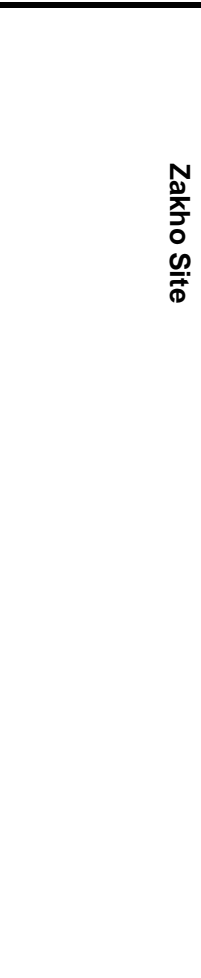 }} & & \multirow{9}{*}{ 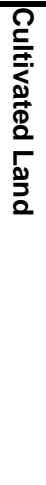 } & A1 & 6.602 & 0.13002 \\
\hline & & & & A2 & 6.181 & 0.06732 \\
\hline & & & & $\overline{A 3}$ & 5.76 & 0.09405 \\
\hline & & & & B1 & 6.255 & 0.34221 \\
\hline & & & & B2 & 5.874 & 0.16797 \\
\hline & & & & B3 & 5.494 & 0.14553 \\
\hline & & & & C1 & 5.908 & 0.04092 \\
\hline & & & & C2 & 5.568 & 0.43428 \\
\hline & & & & C3 & 5.229 & 0.04653 \\
\hline & & & \multirow{9}{*}{ 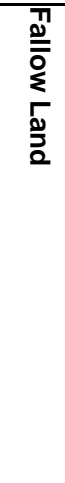 } & A1 & 5.063 & 0.05742 \\
\hline & & & & A2 & 5.112 & 0.07458 \\
\hline & & & & A3 & 5.161 & 0.04884 \\
\hline & & & & B1 & 4.43 & 0.04785 \\
\hline & & & & B2 & 4.444 & 0.04257 \\
\hline & & & & B3 & 4.458 & 0.1485 \\
\hline & & & & C1 & 3.797 & 0.03168 \\
\hline & & & & C2 & 3.776 & 0.12606 \\
\hline & & & & C3 & 3.755 & 0.04917 \\
\hline & & & \multirow{9}{*}{ 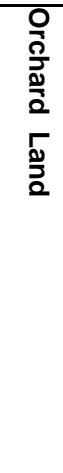 } & $\overline{\mathrm{A} 1}$ & 4.756 & 0.13794 \\
\hline & & & & A2 & 4.192 & 1.485 \\
\hline & & & & A3 & 3.629 & 0.09768 \\
\hline & & & & B1 & 7.521 & 0.03267 \\
\hline & & & & B2 & 5.953 & 0.15279 \\
\hline & & & & B3 & 4.386 & 0.13563 \\
\hline & & & & C1 & 10.286 & 0.28809 \\
\hline & & & & C2 & 7.714 & 0.02541 \\
\hline & & & & C3 & 5.143 & 0.86295 \\
\hline
\end{tabular}

3.1.2.3. The comparison between the sorptivity and transmissivity terms of Philip model for two sites under different landuses:

To reveal the comparisons between parameters of Philips model, there are various results from Tables (3.3, and 3.4) show that the minimum values of sorptivity term Philip model was located in Zakho site orchard lands silty loam $3.629 \mathrm{~cm} \mathrm{t}^{-1 / 2}$, Whilst also the maximum value of sorptivity parameter was situated in Semel site orchard land silty clay $21.762 \mathrm{~cm} \mathrm{t}^{-1 / 2}$ , and the remaining values of sorptivity parameters were intermediate between two extreme values. Consequently the results it also obtain that the minimum values of transmissivity term of Philip model was sited in Zakho site orchard land silty loam $0.02541 \mathrm{~cm} \mathrm{hr}^{-1}$ and the highest value of transmissivity term in Semel site for Orchard land $2.297 \mathrm{~cm} \mathrm{hr}^{-1}$, and the others test values intermediate between two extreme values.

The result agreements with Amin, (2008); Haneyeh Mazloum and Hamidreza Foladmand (2013) they were Shawn the a lot of parameters

akram.khalaf@uod.ac 
of Philip model in Islamic Azad University Mardash branch by single and double ring infiltrometer; Igbadun H. E., et al
(2016);Nugroho Suryoputro, et al (2018), Yan Xin, Yun Xie et al (2019)

\subsection{Evaluation of Infiltration Models:}

\subsubsection{Statistic Indexes:}

Table (3.5): Shows statistics indexes evaluation of two infiltration models (Kostiakov, and Philip) for the studied sites of Semel, and Zakho) under three different types of landuses.

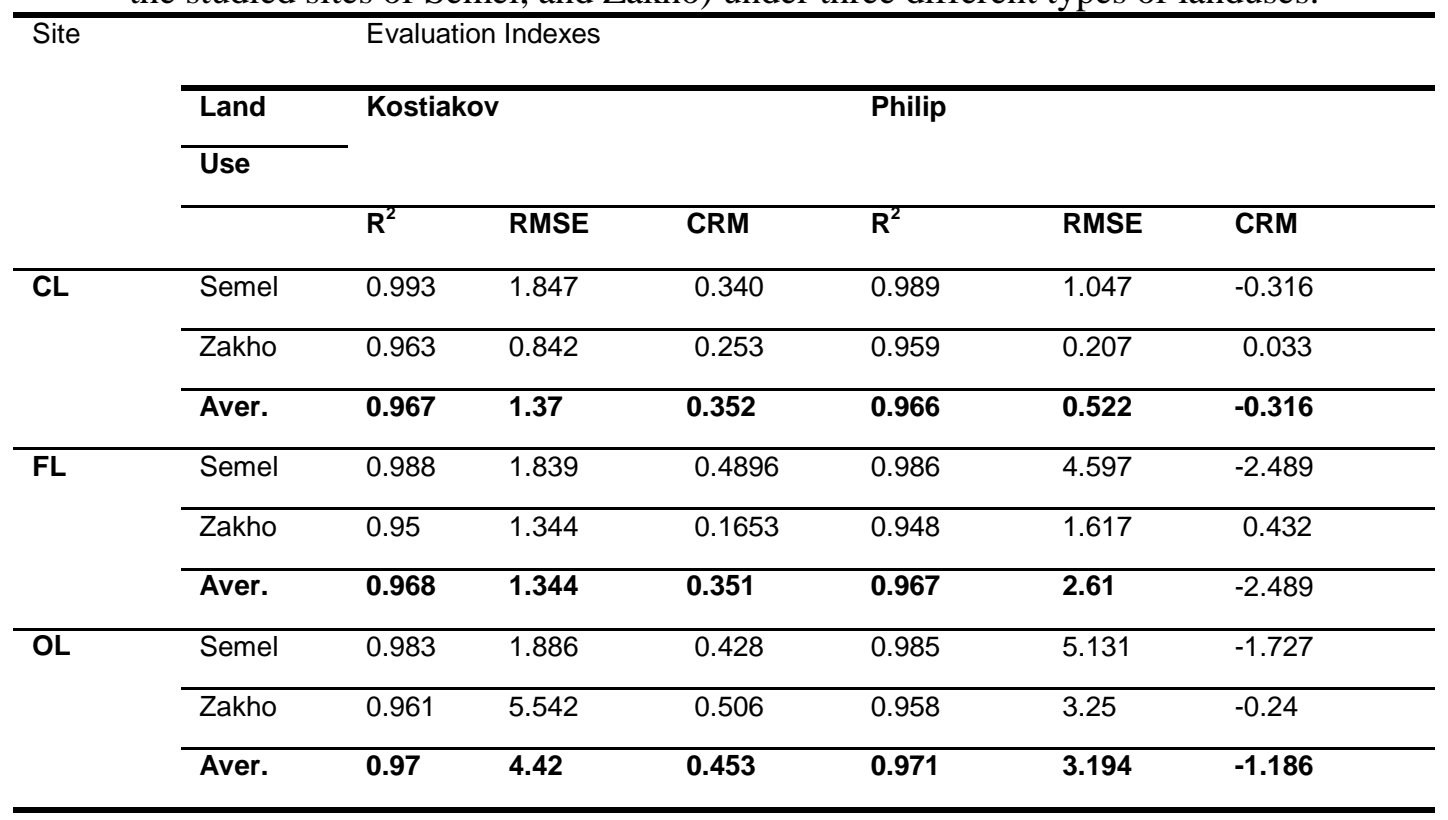

Comparing infiltration models with field data, it is observed that infiltration rate versus time plots for field data and modelled data do not accurately match; but Philip's model is much closer to observed field data having $\mathrm{R}^{2}$, RMSE and CRM values of 0.9660 .5223 and -0.3168 $(\mathrm{mm} / \mathrm{h})$, respectively as average values (Table 3.5) for two soils sites of (Semel, and Zakho) and under same landuse of CL. As concern to the results of this study under FL landuse of the mentioned soils sites have led us to conclude that Kostiakov model, having $\mathrm{R}^{2}$, RMSE and CRM values of $0.9688,1.3441$ and 0.3519 $(\mathrm{mm} / \mathrm{h})$, respectively, is the most suitable for compared to, Philip, model for studied soils (Table 3.5).

Also, from same Table the results of this study under OL landuse revealed that the Philip model with indexes: R2, RMSE, and CRM values of $0.9713,3.1941$ and $-1.1868(\mathrm{~mm} / \mathrm{h})$, respectively gave the better fit than the Kostiakov model.

\section{CONCLUSIONS}

From finding of the current investigate the following points it can be concluded:

1-Parameterization of infiltration models:

1.1 The maximum variation of Kostiakov parameters ( $c$ and $n$ ) for each two location was observed from Zakho site with the variation of saturation hydraulic conductivity under the different soil moisture content and bulk density. It could be mentioned from the results that the higher infiltration with higher Kostiakov $\mathrm{C}$ while lower infiltration was associated with lower value.

1.2 The greatest variation of sorptivity (S) parameter of Philip model has been identified from Semel site furthermore the highest variation of Philip transmissivity was observed from Semel site.

2- Infiltration models evaluation revealed that the Philip model is the most suitable for CL and OL and Kostiakov model FL landuses for the two investigated sites of Semel, and Zakho.

\section{REFERENCES}

Amin Z. A., (2008). Analysis of fitting parameters for infiltration models through different textured soil, Phd, dissertation, University of Salahaddin.

Black, C. A., D. D. Evans, J. L. White, L. E. Ensminger and F. E. Clark. (1965). Methods of Soil Analysis. American Society of Agronomy.

akram.khalaf@uod.ac 
Day, R.P. (1965). Pipette method of particle size analysis. In: Methods of soil analysis. Agronomy 9.ASA USA.p. 553-562.

Gardner, W. (1986). Water Content p. 493-544. In A. Klute (ed.) Methods of Soil Analysis. Part 1, 2nd ed. Soil Science Society of America, Madison, WI.

Hillel, D. (1998). Environmental Soil Physics. Academic Press. San Diego, CA.

Igbadun H. E., Othman M. K. \& Ajayi A. S., I. (2016). Performance of Selected Water Infiltration Models in Sandy Clay Loam Soil in Samaru Zaria. Global Journal of Researches in Engineering: General Engineering, 16(4).

International Standard (ISO) 11277 (1998): Soil quality- Determination of particle size distribution in mineral soil material- Method by sieving and sedimentation.

Jackson, M.L. (1958) . Soil chemical analysis. Prentice-Hall, Englewood Cliffs, N.J. 498 p.

Khalaf, A. (2010). Approach to Evaluate the Sealing Performance of Local Materials for Seepage Reduction. Phd, dissertation, University of Salahaddin.

Mazloom. H, Foladmand.H. (2013). Evaluation and determination of the coefficients of infiltration models in Marvdasht region, Fars province. International journal of Advanced Biological and Biomedical Research, 1(8), pp.: 822-829.

Nugroho suryoputro, Suhardjono A,D, N. and Ery S. Suhartanto DF, W. (2018). Evaluation of infiltration models for mineral soils with different land uses in the tropics. Journal of water and land development, 37(PL ISSN 1429-7426, e-ISSN 2083-4535), pp.153-160.

Oguike P.C., U. (2018). Evaluation of Philip's and Kostiakov's Infiltration Models on Soils Derived from three Parent Materials in Akwa
Ibom State, Nigeria. Journal of Scientific and Engineering Research, 56(2394-2630), pp.7987.

Oram, B. (2005). Hydrological Cycle. Watershed Assessment, Education, Training, Monitoring Resources in Northeastern Pennsylvania. Wilkes University. Environmental Engineering and Earth Sciences Department. Wilkes-Barre,PAhttp://www.water-research. net/watershed/hydrologicalcycle.htm accessed 8/29/06.parameters of Kostiakov and Modified Kostiakov infiltration equations. World Appl. Sci. J., 2011, 15(1), 129-

Parveen Si, Tiwari N.K., Subodh R. (2017). Estimation and inter-comparison of infiltration models. Global Journal water science, 31, Issue1.pp.34-43

Rawls, W. J., L. R. Ahuja, D. L. Brakensiek, A. Shirmohammadi. (1993). Infiltration and soil water movement. In Handbook of Hydrology. McGraw-Hill, Inc.

Shirmohammadi, A. and Skaggs R. W. (1984). Effect of soil surface conditions on infiltration for shallow water table soils. Transactions of the ASAE 27(6): 1780-1787.

Turner, E. (2006). Comparison of Infiltration Equations and Their Field Validation by Rainfall Simulation. Thesis submitted in partial fulfillment of the requirements for the degree of Master of Science to the Faculty of the Graduate School of the University of Maryland, United States of America.

Yan Xin, Yun Xie and Yuxin Liu, (2019). Effects of Residue Cover on Infiltration Process of the Black Soil under Rainfall Simulations. Journal of water and land development, 37(14297426, e-ISSN 2083-4535), pp.153-160. 
دهستنيشانكرن و هه لسهنكاندنا موديلّين جوونا زوورا ئافي د ئاخيّ دا زبو ئاخين دوو دهشتان ييّن ده

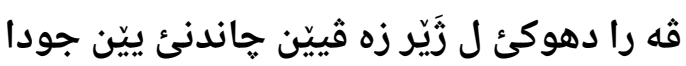

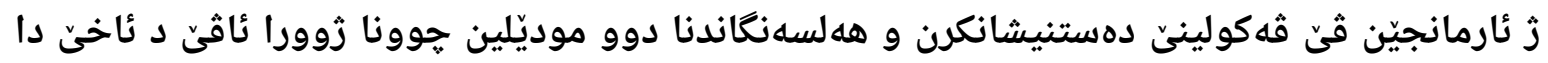

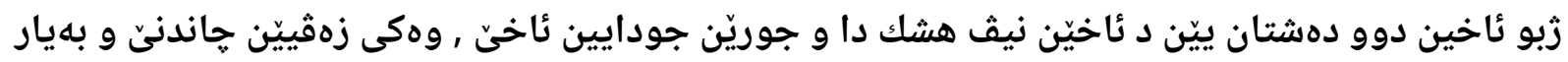

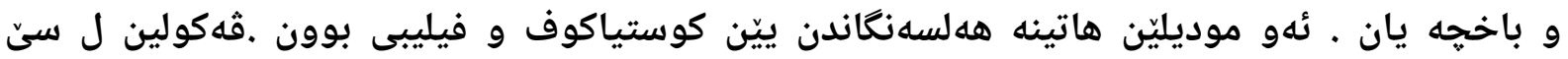
دهثهران هاتيه ئهنجام دان و ل دوو دهشتيّن سهرهكى ل ياريّزكه ها دهوكي ل ههريّما كوردستانا عيراقيّ . ههردوو موديّلين باشترين شيوه دهركه فتين كوستياكوف و فيليب بون , دهربارهى ييّن گريّدايى موديلى

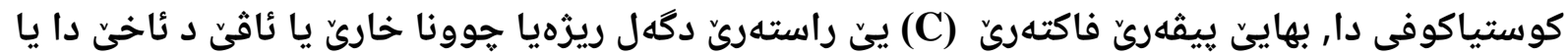

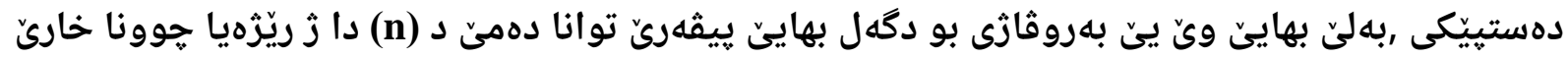

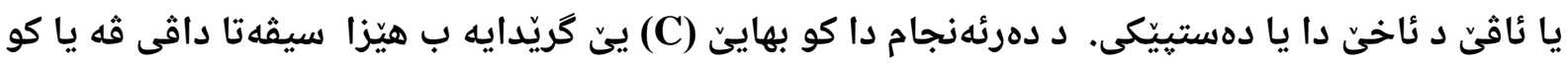

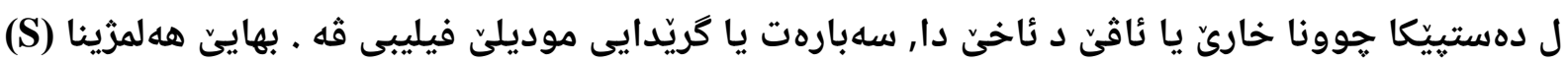

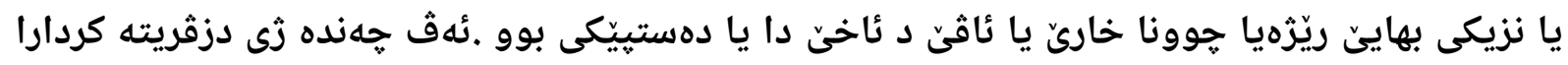

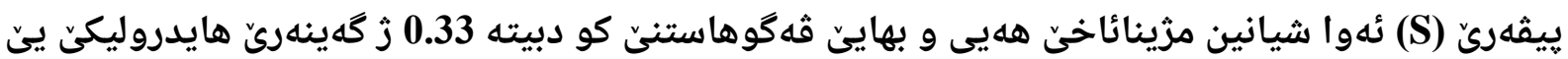
ئاخا تيّركرى زئَاقيّ.

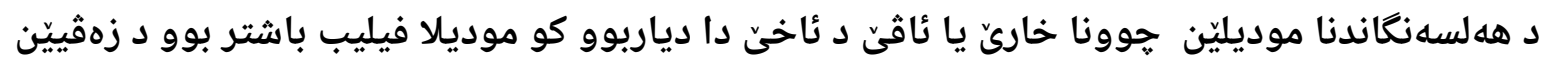

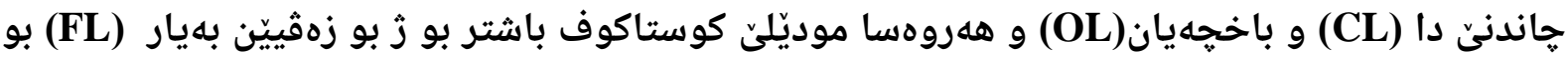

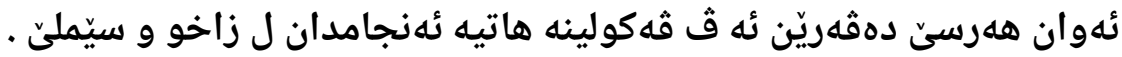

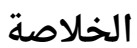

معاييرة وتقييم نماذج الارتشاح لسهلين رئيسيين تحت استعمالات مختلفه في منطقة دهوك

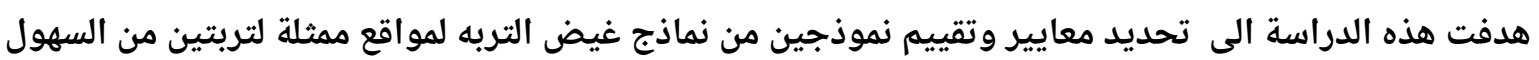

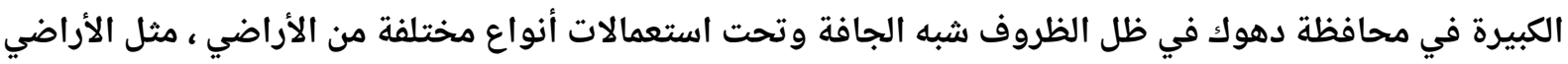

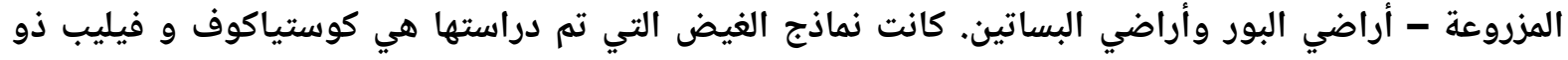

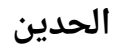
تم إجراء البحث في الموقعين اللذين يمثلان سهلين رئيسيين في محافظة دهوك في إقليم كردستان العراق

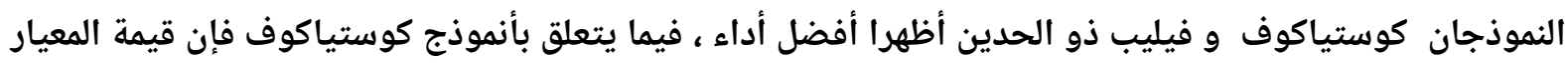

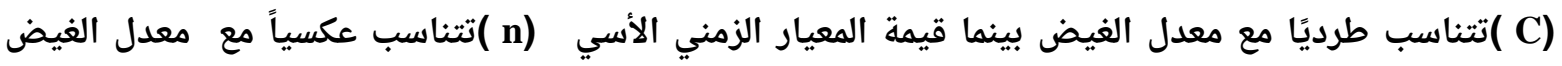

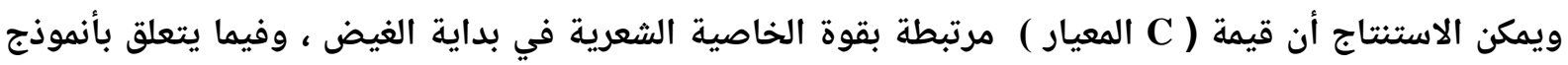

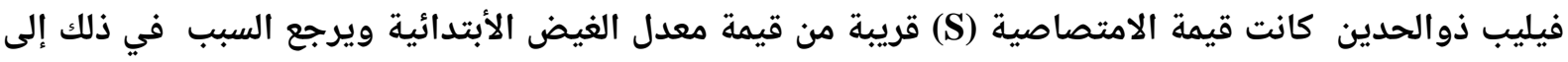

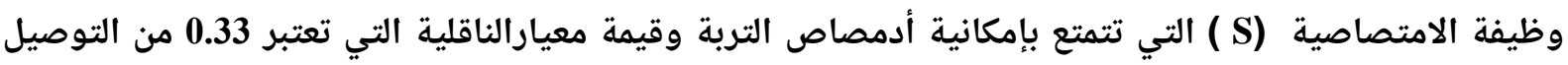
الهيدروليكي المشبع للتربة.

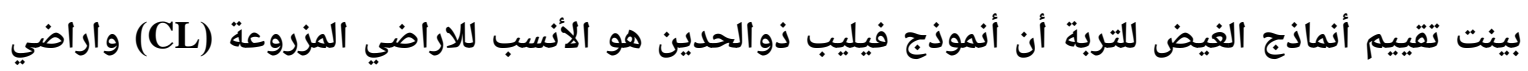
البساتين (OL) و أنموذجكوستياكوف لاراضى البور (FL) للموقعين التي تم شملتها الدراسة في سهليسميل و زاخو. 